\title{
Probabilistic Assessment of Shale Gas Production and Water Demand at Xiuwu Basin in China
}

Youqin Zou ${ }^{\mathrm{a}, \mathrm{b} *}$,Changbing Yang ${ }^{\mathrm{c} *}$,Daishe $\mathrm{Wu}^{\mathrm{a}, \mathrm{b}}$, Chun Yan $^{\mathrm{d}}$, Masun Zeng ${ }^{\mathrm{e}}$, Yingying Lan ${ }^{\mathrm{f}}$, and Zhenxue Dai ${ }^{\mathrm{g}}$

*Corresponding authors: Changbing Yang (changbing.yang@beg.utexas.edu) and Youqin Zou (zouyouqin@ncu.edu.cn)

\section{AUTHOR ADDRESS}

${ }^{a}$ School of Resources, Environmental and Chemical Engineering, Nanchang University,Nanchang 330031, Jiangxi, China

${ }^{\mathrm{b}}$ The Key Laboratoryof Poyang Lake Ecology and Bio-resource Utilization, Nanchang University, Ministry of Education, Nanchang, 330047, Jiangxi, China

${ }^{\mathrm{c} B u r e a u}$ of Economic Geology, The University of Texas at Austin, Austin, Texas, USA

${ }^{\mathrm{d} J i a n g x i}$ Institute of Geo-Environment Monitoring, Nanchang 330095, Jiangxi, China

${ }^{\mathrm{e}}$ Jiangxi Province Investigation, Design \& Research Institute, Nanchang 330095, Jiangxi, China

${ }^{f}$ Nanchang Institute of Technology, Nanchang, 330099, Jiangxi, China

${ }^{g}$ Earth and Environmental Sciences Division, Los Alamos National Laboratory, Los Alamos, NM, USA, 87545

(C) 2016. This manuscript version is made available under the Elsevier user license http://www.elsevier.com/open-access/userlicense/1.0/ 


\begin{abstract}
This study presents an integrated probabilistic framework by combining Monte Carlo Simulation with a gas transport model of a horizontal well with multi-fracturing stages to assess shale gas resources in the Wangyinpu Formation of the Xiuwu Basin, China. Modeling results suggest that the 30-year cumulative production of a single horizontal well is predicted at a likely value of $3.50 \times 10^{8} \mathrm{~m}^{3}$ with a maximum of $6.78 \times 10^{9} \mathrm{~m}^{3}$. Potential shale gas production from a "sweet spot" area is estimated at a range of $1.13 \times 10^{10} \mathrm{~m}^{3}$ to $1.76 \times 10^{13} \mathrm{~m}^{3}$ with a likely value of $8.24 \times 10^{11} \mathrm{~m}^{3}$. Sensitivity analysis indicates that the gas production rate and cumulative gas production of a single horizontal well are most sensitive to the relative volume occupied by kerogen in the bulk volume of the shale, gas desorption rate, number of fracturing stages, and permeability of the stimulated zone. Assessment of water demand for horizontal well drilling and hydraulic fracturing suggests that shale gas development at the Xiuwu Basin will not likely cause regional water-supply stress because of abundant water resources in the region. The probabilistic approach presented in this study can provide valuable information for planning shale gas development and can also be applied to other shale gas reservoirs.
\end{abstract}

\title{
KEYWORDS
}

Shale gas; Probabilistic analysis; Monte Carlo simulation; Water consumption; Sensitivity analysis 


\section{Introduction}

Owing to advances in technologies of horizontal well drilling and hydraulic fracturing in the last decade, unconventional development of natural gas from shale formations, which were previously not considered as technically recoverable resources, has been considered a promising energy supply in some regions of the world [1-6].Tens of thousands of horizontal wells have been drilled in shale formations to extract natural gas [7]. The significant increase in natural gas production has stimulated global business and policy interest in unconventional gas development. China was reported to likely have the world's largest amount of shale gas reserves, estimated at about 134 trillion $\mathrm{m}^{3}$ [8]. Inspired by the successful development of shale gas in the United States and other countries and motivated to reduce its dependence on energy imports and to decrease greenhouse gas emissions from coal power plants, China has actively pursued exploration and development of shale gas resources and set an ambitious goal to boost annual shale gas production to $60 \times 10^{9} \mathrm{~m}^{3}$ by 2020 [9]. However, because exploitation of shale gas in China is at a very early stage, China faces various challenges in shale gas development, such as reliable assessment of shale gas resources in shale gas reservoirs [10-12]. As of May 2014, only about 184 horizontal wells were drilled in shale gas reservoirs, resulting in a daily production of $3.8 \times 10^{6} \mathrm{~m}^{3}$. Most of production wells were primarily located in the Sichuan Basin, southwestern China .

Shale gas reservoirs present numerous challenges in terms of resources assessment because they are typified by large yet uncertain area extents, as well as complex geological, petrophysical, and geomechanical factors. Various methods have been reported for assessing shale gas resources which can generally be classified as deterministic and probabilistic [13]. A deterministic method typically uses a single value for each parameter in the estimation of shale 
gas resources and potentially neglect the uncertainties associated to the parameters and may lead to overly optimistic results of shale gas resources. A probabilistic method can take into account uncertainties inherited in parameters required for estimation of shale gas resources and may be more appropriate and provide better estimation of shale gas resources with a statistical distribution of all possible outcomes. Compared to the vast amount of literature about application of deterministic methods of shale gas resources assessment, to date, very few with probabilistic methods are available $[14,15]$. Gary et al. pointed out that much of the uncertainty inherent in shale gas reservoirs could not be appropriately quantified through deterministic analysis and hence decision making for shale gas development based on results with a deterministic method would be biased. A probabilistic method usually uses Monte Carlo simulations to simulate uncertainties which are integrated with either a volumetric method [16], rate-transient analysis [17-19], or numerical simulation [20,21]. The volumetric method is limited because of the poor estimation in fraction of gas-in-place that can be recovered, although the recent advancement in core and petrophysical analyses may improve this method for resource assessment [22]. Based on semi-analytical or empirical models, rate-transient analysis is one of the most widely used methods for projecting shale gas production from the historic data [23]. However this method has various limitations which were discussed in literature, such as oversimplification of gas flow in shale $[24,25]$. Most existing numerical simulations could be categorized into two groups: the explicit hydraulic-fracture (EHF) modeling method and the stimulated reservoir volume (SRV) method $[7,26,27]$. Compared to the EHF method, the SRV method is relatively simple. The EHF method needs precise geometry and distribution of hydraulic fractures generated during the hydraulic fracturing in a shale reservoir. A SRV method simplifies the fractured shale between two major fractures (stages) as homogenous porous media with enhanced permeability, resulted 
from the hydraulic fracturing [26]. In addition, an EHF method simulates gas flow in a 3D domain while a SRV simulates gas flow in a 1D domain.

The Xiuwu basin is located in the northern part of Jiangxi province, China (Figure 1). Preliminary results from the pilot well drilling, outcrop measurements, and geophysical survey suggest that the Lower Cambrian organic-rich marine shale, the Wangyinpu Formation, is rich in natural gas at the Xiuwu basin [28-32]. Shale gas resources were estimated at roughly $\sim 2.92 \times 10^{11} \mathrm{~m}^{3}$ using a deterministic volumetric method [29]. The local government of Jiangxi province in China initialized a 10-year plan for shale gas development and set a goal to achieve shale gas production of $3 \times 10^{8} \mathrm{~m}^{3} / \mathrm{y}$ at the Xiuwu Basin by 2020 [33]. However, the questions remained are: (1) how the estimation of shale gas resources at the Xiuwu Basin with the deterministic volumetric method is reliable, and (2) whether the development goal of shale gas resources, set by the local government is achievable. In this study, an integrated probabilistic framework by combining the SRV method with Monte Carlo simulations is proposed and used to address the two questions. Because no any production well has been drilled at the Xiuwu Basin, the rate-transient analysis could not be used in this study. Because of a similar reason, the EHF method was not used either because this method requires detailed geometrical information about fractures in the stimulated reservoir which are unavailable. In addition, the EHF method generally requires huge computational efforts, especially coupled with the Monte Carlo method, because of more than thousands of realizations of parameter sets are simulated.

Hydraulic fracturing for shale gas development usually requires a significant amount of water compared to conventional drilling and completion techniques [10, 34-36]. Table 1 summarizes water use for horizontal well fracturing reported in literature. It can be seen that water use per horizontal well varies significantly both across shale formations and within each formation. Most 
areas in China have a shortage of water resources. Challenges associated with the demands for water from China's shale gas industries were noticeable [10-12]. One concern is water demand in developing shale gas resources at the Xiuwu Basin. With the help of the model developed in this study, we want to assess whether water resources in the region is supportive to shale gas development at the Xiuwu Basin.

The main objectives of this study are: (1) develop an integrated probabilistic framework to reliably assess shale gas resources that can be valuable to achieving the goal, set in the 10-year plan, of shale gas development at the Xiuwu Basin; 2) evaluate impacts of parameter uncertainty on modeling results with global and local sensitivity analysis; and 3) to predict water demand and assess potential environment impacts for shale gas development at the Xiuwu Basin. To the

best of our knowledge, this study is the first to apply an integrated probabilistic framework by combining the stimulated reservoir volume method with Monte Carlo simulations to provide statistical estimation of shale gas resources and water demand at a shale gas reservoir which has limited data and no production wells yet. The probabilistic framework can be further integrated into economic models for assessing economic impacts of shale gas development.

\section{The Wangyinpu Formation at the Xiuwu Basin}

Previous studies on geological conditions of the Wangyinpu Formation are summarized in Table 2. The shale formation was located at depths varying from $1,500 \mathrm{~m}$ to $3,500 \mathrm{~m}$, with a net thickness of $100 \mathrm{~m}$ to $400 \mathrm{~m}$ and a gradual increasing trend from northwest to southeast (Figure 1). The Wangyinpu Formation and two other shale formations in China (Permian shale in the Lower Yangtze region, Eastern China, and Lower Cambrian shale in Northern Guizhou province, South China) are thicker than shale formations in the United States and Canada (Figure A1). 
Burial depth of the Wangyinpu Formation is similar to that of the Devonian Marcellus shale in the Appalachian Basin (Figure A1). Total organic carbon (TOC) is one of the key factors in a shale formation for the generation of shale gas as well as for providing surface areas for adsorbed gases. TOC varies from $1.4 \%$ to $15.5 \%$ estimated for samples collected from outcrops and from $3.2 \%$ to $14.2 \%$ estimated for samples collected from pilot well ranges, suggesting no significant difference in TOC measured at the rock samples collected either in the pilot well or from the outcrops. TOC in the Wangyinpu Formation is similar to that reported in the Devonian Woodford shale in south-central Oklahoma (Figure A1).Thermal maturity and vitrinite reflectance $\left(\mathrm{R}_{\mathrm{o}}\right)$ are other important parameters used in the evaluation of shale gas resources. Measured $\mathrm{R}_{\mathrm{o}}$ ranges from $2.0 \%$ to $4.5 \%$ with an average of $3.2 \%$, showing a general trend of gradual increase from south to north in the study area. Apparently, thermal maturity of TOC is higher in the Wangyinpu Formation than in 12 other shale formations worldwide (Figure A1).

Observation of rock samples collected from the outcrops and pilot well with scanning electron microscopy (SEM) shows that natural fractures are abundant with apertures of $\sim 1 \mu \mathrm{m}$, with few wider than $10 \mu \mathrm{m}$ [29]. Pore size mainly ranges from 1 to $10 \mu \mathrm{m}$ based on rock samples collected from outcrops [29].Porosity of the Wangyinpu Formation ranges from $1 \%$ to $8 \%$ with an average of $2.6 \%$, relatively smaller than that of shale formations in the United States (Figure A1). Permeability measurements of the Wangyinpu Formation show significant variations from $0.004 \mathrm{mD}$ to $0.2 \mathrm{mD}$ with an average of $0.022 \mathrm{mD}$ [29]. Shale gas content was estimated from onsite gas desorption of rock samples and laboratory experiments of gas sorption isotherms. Gas content was measured at 0.1 to $0.38 \mathrm{~m}^{3} / \mathrm{t}$ on the basis of onsite desorption of rock samples, much smaller than that estimated from the laboratory experiments of gas sorption isotherms, which show maximum gas capacity of $7.91 \mathrm{~m}^{3} / \mathrm{t}$ at Langmuir pressure of $1.75 \mathrm{MPa}$. 
The significant difference in gas content estimated with the two methods is likely because(1) rock samples for onsite desorption are collected at relatively shallow depth (660 m to $840 \mathrm{~m}$ ), and (2) natural fractures are abundant so that gas could not be well preserved when rock samples are brought to the surface[29]. The Wangyinpu Formation has gas content similar to that of the other two shale formations, but lower than the Mississippian Barnett shale in the Fort Worth Basin, the Upper Jurassic Haynesville Formation in the North Louisiana salt basin, and the Devonian-Mississippian strata in the western Canada sedimentary basin (Figure A1).

Content of brittle minerals (usually quartz, feldspars, and calcites) is a key indicator that a shale formation is frackable. Generally, a shale reservoir is favorable for economic development if the content of brittle minerals is greater than $40 \%$ and that of clay minerals less than $30 \%$. Mineralogical analysis of the Wangyinpu Formation indicates that the shale contains $40 \%$ to $80 \%$ brittle minerals, mainly quartz with few calcites and feldspar, and $6 \%$ to $45 \%$ clay minerals such as illite, smectite, chlorite, and kaolinite. The shale contains up to 5.6\% pyrite. Clay minerals and pyrite increase gradually from the bottom to the top of the Wangyinpu Formation. Quartz shows strong heterogeneity vertically, and feldspars are relatively uniformly distributed along the vertical profile. Calcite and dolomite are found at the bottom of the formation, mainly as fillings in the natural fractures in shale. High quartz content in the Wangyinpu Formation likely is due to recrystallization during the late diagenesis [30].

\section{Methods}

\subsection{Stimulated reservoir volume method}

A schematic of the stimulated reservoir volume for a horizontal well with multiple fractures (stages) is shown in Figure 2a. The horizontal portion of the well crosses the major fractures. 
After completion of the well, gas flows in the stimulated reservoir volume between two adjacent fractures is simulated with a simple 1D model, as shown in Figure 2b [27],

$$
\left(c_{g} \emptyset+\rho_{0} \rho_{k} S_{k} c_{f}\right) \frac{\partial p}{\partial t}=\frac{\partial}{\partial x}\left(\frac{\kappa}{\mu} \frac{\partial p^{2}}{\partial x}\right)
$$

where $p$ is pressure $(\mathrm{Pa}), x$ is the coordinate orthogonal to the fracture plane $(x=0$ represents the fracture surface, $\mathrm{m}$, and $x=\mathrm{D}_{\mathrm{f}}$ represents the no-flux boundary at the half-distance between the two adjacent major fractures, as shown in Figure $2 b), \phi$ is porosity $(-), \rho_{o}$ is shale gas density at normal condition $\left(0.717 \mathrm{~kg} / \mathrm{m}^{3}\right.$ in this study), $\rho_{k}$ is density of organics in shale (or kerogen, 1250 $\left.\mathrm{kg} / \mathrm{m}^{3}\right), S_{k}$ is volume ratio of kerogen in shale $(-), c_{f}$ is gas desorption rate at depleting pressure $\left(\mathrm{m}^{3} /(\mathrm{kg} . \mathrm{Pa})\right), \kappa$ is permeability $\left(\mathrm{m}^{2}\right), \mu$ is dynamic viscosity $(\mathrm{Pa} \cdot \mathrm{d}), \mathrm{c}_{g}\left(=\frac{M}{Z R(T+273.15)}\right)$ is compressibility, $M$ is molar mass of shale gas $(16.042 \mathrm{~g} / \mathrm{mol}), R\left(=8.314472 \mathrm{~m}^{3} \mathrm{~Pa} /(\mathrm{K} \cdot \mathrm{mol})\right)$ is the universal gas constant, $Z$ is compressibility factor (-), and $T$ is temperature $\left({ }^{\circ} \mathrm{C}\right)$. Note that the 1D model domain is represented by the portion of the stimulated zone from one main fracture to the half-distance of the adjacent major fracture (Figure 2b). The 1D model neglects the pressure gradient within the major fractures; gas pressure in the major fractures is equal to pressure in the well, $p_{w}$. The gas transport model in Equation 1 assumes a single gas phase flow with desorption from organics in shale which can be simulated with a linear model with a constant desorption rate [27].

Eq. (1) of gas transport is subject to the following boundary and initial conditions,

$$
\left\{\begin{array}{c}
\left.p\right|_{x=0}=p_{w} \\
\left.\frac{\partial p}{\partial x}\right|_{x=D_{f}}=0 \\
\left.p\right|_{t=0}=p_{r}
\end{array}\right.
$$


where $\mathrm{p}_{\mathrm{r}}$ is reservoir pressure $(\mathrm{Pa})$ at the initial time, $\mathrm{p}_{\mathrm{w}}$ is the well pressure $(\mathrm{Pa})$. The pristine reservoir rock, outer of the stimulated zone, is assumed to be impermeable, or a no-flow boundary condition (Figure $2 b$ ).

Gas production rate, $\mathrm{Q}(\mathrm{t})$, can be calculated as

$$
Q(t)=-2 N A \frac{c_{g}}{\rho_{o}} \frac{\kappa}{\mu} \frac{\partial p^{2}}{\partial x}
$$

where $N$ is the number of major fractures (stages) and $A$ is the surface area of major fractures.

A finite difference method was applied to solve Eq. (1) with the initial and boundary conditions defined in Eq. (2). Note that the rock volume between two major fractures shown in Figure 2B is equal to the product of distance between the two main fractures (stages) multiplied by the surface area of the fractures which are perpendicular to the horizontal well.

\subsection{Sensitivity analysis}

Sensitivity analysis (SA) is critical in modeling assessments of shale gas production because model parameters are uncertain which may stem from the combination of spatial heterogeneity and insufficient measurements caused by technological and economic limitations. SA aims to quantify and rank the relative importance or impact of each input parameter on performance measures of model output when input parameters are varying. SA tells about how model outputs (gas production rate and cumulative gas production in this study) depend on the uncertain parameters. Two types of sensitivity analysis-local relative sensitivity and global sensitivity — have been widely used. Local relative sensitivity is calculated with the following

equation by adding a standard deviation, $\sigma_{i}$, to the average value, $\bar{X}$ of the i-th parameter $[37,38]$,

$$
L S P_{i}=\frac{\left[\frac{Y\left(\bar{X}_{i}+\sigma_{i}\right)-Y\left(\bar{X}_{i}\right)}{Y\left(\bar{X}_{i}\right)}\right]}{\bar{\sigma}_{i}}
$$


and by subtracting standard deviation, $\sigma_{i}$, from the average value, $\bar{X}$ of i-th parameter,

$$
\operatorname{LSN}_{i}=\frac{\left[\frac{Y\left(\bar{X}_{i}-\sigma_{i}\right)-Y\left(\bar{X}_{i}\right)}{Y\left(\bar{X}_{i}\right)}\right]}{\frac{\sigma_{i}}{\bar{X}_{i}}}
$$

Note that LSPQ and LSPCQ stand for the relative sensitivity of gas production rate and cumulative gas production to model parameters using Eq. 4 while LSNQ and LSNCQ represent for the relative sensitivity of gas production rate and cumulative gas production to model parameters using Eq. 5. One disadvantage of local sensitivity is that interactions among the 12 model parameters listed in Table 3, which may have much more significant impacts on the model output, are neglected. A global sensitivity analysis, Sobol's sensitivity, was used in this study by considering the whole variation range of an uncertain parameter to quantify contributions from both interactions among parameters [39, 40]. Sobol's method is variance-based. The first-order index, $G S_{i}$, and the total sensitivity index, $G S t_{i}$, of the i-th parameter, are calculated with the following equations,

$$
\begin{aligned}
G S_{i} & =1-\frac{1}{\sigma_{y}^{2}} \frac{1}{2(n-1)} \sum_{m=1}^{n}\left(a_{m}-c_{i, m}\right)^{2}, \\
G S T_{i} & =\frac{1}{\sigma_{y}^{2}} \frac{1}{2(n-1)} \sum_{m=1}^{n}\left(b_{m}-c_{i, m}\right)^{2}
\end{aligned}
$$

where $\mu_{y}$ and $\sigma_{y}^{2}$ are the overall sample mean and variance of model output, and $\mathrm{a}_{\mathrm{m}}, \mathrm{b}_{\mathrm{m}}$, and $\mathrm{c}_{\mathrm{i}, \mathrm{m}}$ are the modeling results of parameter sets $\mathrm{A}, \mathrm{B}$, and $\mathrm{C}_{\mathrm{i}}(\mathrm{i}=1, . ., \mathrm{k})[39,40]$. The first-order index, $G S_{i}$, is a measure for the variance contribution of the individual model parameter to the total model variance while the total sensitivity index, $G S T_{i}$, detects interactions of an individual parameter with all other parameters, representing total variance contribution to the model output. If the total sensitivity index of an individual input parameter is negligible, then the interaction of this input parameter with other input parameters is non-relevant. Parameter sets A and B are each 
an $\mathrm{n} \times \mathrm{k}$ matrix containing $\mathrm{n}$ sets of $\mathrm{k}$-dimensional parameter vectors generated with the Monte Carlo method $[39,40]$. Parameter set $C_{i}(i=1, . ., k)$ was created from A and B such that the $i$-th column of $\mathrm{C}_{\mathrm{i}}$ is the same as the $\mathrm{i}$-th column of $\mathrm{A}$, and the other columns of $\mathrm{C}_{\mathrm{i}}$ are the same as $\mathrm{B}$. In this study, $\mathrm{k}=12$ and $\mathrm{n}=20,000$. Note that GSiQ and GSiCQ represent the first-order indices for gas production rate and cumulative gas production to model parameters using Eq. 6 while GSTiQ and GSTiCQ represent the first-order indices for gas production rate and cumulative gas production to model parameters using Eq. 7.

\subsection{Probabilistic analysis}

Because no production well has been drilled at the Xiuwu Basin, model parameters are assumed to have ranges and probability distributions on the basis of available data from the field and also from literature (Table 3). Total 40,000 realizations were simulated with the Monte Carlo

method for each model parameter and then input to the SRV model. Modeling results of cumulative gas production from a single well was further used to assess shale gas resources at the "sweet spot" delineated in the Xiuwu Basin by considering horizontal well number which could be drilled on a basis of average well spacing reported in literature. Water demand for drilling and hydraulic fracturing at the Xiuwu Basin was evaluated by multiplying water consumption for a single horizontal well and number of horizontal wells that could be drilled. Both water consumption for a single horizontal well and the number of horizontal wells were simulated with the Monte Carlo method.

\section{Results and discussion}

\subsection{Modeled gas production rate and cumulative production from a horizontal well}


Modeled gas production rate and cumulative gas production from a single horizontal well for the 40,000 realizations as a function of time are shown in Figure 3. Gas production rate shows an overall decreasing trend (Figure 3a), and cumulative gas production gradually increases with time over a period of 30 years (Figure 3b). It can also be seen that both gas production rate and cumulative gas production show significant variations, with a range of up to 3 to 4 orders of magnitude (Table 4). After 5 years, production rate varies from $1.47 \times 10^{3} \mathrm{~m}^{3} / \mathrm{d}$ to $7.61 \times 10^{5} \mathrm{~m}^{3} / \mathrm{d}$ with a likely value of $4.06 \times 10^{4} \mathrm{~m}^{3} / \mathrm{d}\left(\mathrm{P} 50,50^{\text {th }}\right.$ percentile); after 30 years, production rate decreases to as low as $55.4 \mathrm{~m}^{3} / \mathrm{d}$ with a likely value (P50) of $1.44 \times 10^{4} \mathrm{~m}^{3} / \mathrm{d}$. Predicted cumulative gas production ranges from $5.41 \times 10^{6} \mathrm{~m}^{3}$ to $2.74 \times 10^{9} \mathrm{~m}^{3}$ after 5 years. After 30 years, cumulative gas production may reach as high as $6.78 \times 10^{9} \mathrm{~m}^{3}$ with a likely value (P50) of $3.50 \times 10^{8} \mathrm{~m}^{3}$.

A ratio of $90^{\text {th }}$ percentile to $10^{\text {th }}$ percentile $(\mathrm{P} 90 / \mathrm{P} 10)$ is indicative of a large variation in the best and the worst of the modeled well performance. P90/P10 for production rates are 7.4 after 5 years, 8.2 after 15 years, and 10 after 30 years; P90/P10 for cumulative gas production are 7.3 after 5 years, 7.5 after 15 years, and 7.7 after 30 years, showing a minor change over time compared to that of production rate. According to statistical analysis of production wells in the Barnett Shale within six counties of Texas P90/P10 of estimated ultimate recovery ranges from 3.7 to 5, and P90/P10 of the peak month rate varies from 2.9 to 4.1.[41] Apparently, production rate and cumulative gas production at the Xiuwu Basin show a larger variation than that of the Barnett Shale in Texas. The possible explanations include 1) the selection of the parameters and their probability functions have a large influence on the variations of the predictions. The selection of the pdfs is subjective; and 2) there are more data in the Texas fields and parameter 
uncertainties in Texas wells should be smaller than in the Xiuwu Basin. In addition, ratio of P90/P10 may also depend on well operation [57].

Histogram of gas production rate is shown in Figure A2 with skewness of 2.3 and kurtosis of 13.2. Histogram of cumulative gas production is shown in Figure A3, having same skewness and kurtosis as those of gas production rate. Cumulative gas production has same skewness and kurtosis as gas production rate because cumulative gas production is an integral of gas production rate over time. The large positive value of skewness may indicate an asymmetrical distribution of cumulative gas production or gas production rate with a long tail to the right side while the high kurtosis suggests the distribution having a distinct peak near the mean with a rapidly declining trend and a heavy tail, as shown in Figures A2 and A3. Such high variability in well production rate and cumulative gas production is likely caused by uncertainties in model parameters. If actual production data at the study area is available for model calibration to limit the uncertainties in model parameters, such high variability in gas production rate and cumulative gas production could be reduced.

\subsection{Sensitivity analysis}

Figures 4A and 4B show local relative sensitivity of gas production rate and cumulative gas production to 12 model parameters. Viscosity, compressibility, well pressure and reservoir temperature have negative sensitivity, suggesting that the four parameters are negatively correlated to gas production rate and cumulative gas production. Half distance between the two adjacent fractures, well pressure and reservoir temperature show minor impacts on gas production rate and cumulative gas production. 
Figures 4c and 4d show the Sobol's first-order and the total sensitivity indices of 12 model parameters. For both gas production rate and cumulative gas production, the Sobol's firstorder sensitivity indices of three parameters-reservoir temperature, well pressure, and porosity - are close to zero, while their total sensitivity indices are up to 0.15 , suggesting that the model output is minor sensitive to the three parameters, however, and interactions with other parameters may not be neglected. Both the local relative sensitivity and the Sobol sensitivity analysis show that gas production rate and cumulative gas production are most sensitive to relative volume occupied by kerogen in bulk volume of rock, gas desorption rate, number of stages and permeability of the stimulated zone, indicating that good measurements of the four parameters could potentially reduce uncertainty in assessment of shale gas resources. It is also worth pointing out that the local relative sensitivity indices of the 12 model parameters show little variation over the 30-year time period (Figure 5), while the Sobol's sensitivity indices of some parameters vary with time (Figure 6). It can be seen that the Sobol's sensitivity indices (both first order and total) of permeability (P4) show a decreasing trend over time, indicating that gas transport in the stimulated zone plays a more significant role in the early period of well production than in the later period. Note that the Sobol's sensitivity indices of two parametersgas desorption rate (P7) and relative volume occupied by kerogen in the rock (P8), representing gas desorption from shale_-show an overall increasing trend over time (Figure 6). This suggests that gas desorption gradually plays an important role in gas production rate and cumulative gas production over time. Furthermore, our study confirms also that the global sensitivity analysis could provide us better understanding of dependence of the modeling results on model parameters.

\subsection{Estimate of shale gas resource at a "sweet spot" area}


Pang et al.[29] delineated a "sweet spot" area at the Xiuwu Basin (Figure 1) that is likely favorable for shale gas development because: (1) burial depth of the Wangyinpu Formation is moderate, ranging from $1,000 \mathrm{~m}$ to $3,000 \mathrm{~m}$; (2) TOC content ranges $6 \%$ to $12 \%$; (3) organic maturity is moderate, from $2 \%$ to $3 \%$; (4) thickness of the shale formation is greater than $100 \mathrm{~m}$; and (5) few natural faults are found and shale gas in the shale formation at this area could be preserved over geological time [29]. The "sweet spot" area is $\sim 1,050 \mathrm{~km}^{2}$, approximately onethird of the total area of the Xiuwu Basin. It was reported that well spacing of horizontal wells in the 8 major gas shales in the United States ranges from 60 to 640 acres $\left(0.24 \mathrm{~km}^{2}\right.$ to $\left.2.6 \mathrm{~km}^{2}\right)$ [42]. The number of horizontal wells that could be drilled within the "sweet spot" area was estimated to be from 810 to 4,300 based on the well spacing reported in the literature. Assuming that the number of horizontal wells follows a uniform distribution with a range from 810 to 4,300 , total 40,000 realizations were generated with the Monte Carlo method. Shale gas resources were further obtained by multiplying cumulative gas production after 30 years which was simulated in the SRV model by the number of horizontal wells. Total gas production in the "sweet spot" area is estimated at a range of $1.13 \times 10^{10} \mathrm{~m}^{3}$ to $1.76 \times 10^{13} \mathrm{~m}^{3}$ with a likely value (P50) of $8.24 \times 10^{11} \mathrm{~m}^{3}$

(Table 4; Figure A4). P90/P10 of the total gas production in the "sweet spot" area is 9.4, higher than that of the cumulative gas production in a single horizontal well.

\subsection{Estimate of water demand for drilling and hydraulic fracturing of horizontal wells}

Figure 7 shows status of water resources and water supply/usage from 2008 to 2013 in Jiujiang, where the Xiuwu Basin is located [43]. From 2008 to 2013, annual precipitation varied from $2 \times 10^{10} \mathrm{~m}^{3}$ to $3.5 \times 10^{10} \mathrm{~m}^{3}$, and annual water resources available for use ranged from $1.2 \times 10^{10} \mathrm{~m}^{3}$ to $2.5 \times 10^{10} \mathrm{~m}^{3}$. Surface water holds up to $80 \%$ of total water resources available for 
use in Jiujiang (Figure 7a). From 2008 to 2013 , the annual supply of water varied from $2.4 \times 10^{9}$ $\mathrm{m}^{3}$ to $3 \times 10^{9} \mathrm{~m}^{3}$ (Figure $7 \mathrm{~b}$ ). About $98 \%$ of total water supplied was from surface water (Figure 7b). Water was mainly supplied for agriculture, industry, domestic use, stock, municipal use, and landscaping (Figure 7c). More than half of the water was supplied to agriculture, and about $35 \%$ was used by industry.

Water consumption for a horizontal well in different shale reservoirs varies significantly (Table 1). According to the limited number of horizontal wells drilled in China, water consumption per horizontal well was up to $46,000 \mathrm{~m}^{3}$ with a mean value of $27,000 \mathrm{~m}^{3}$, much higher than that reported in the United States (Table 1). Because actual data of water consumption per horizontal well at the Xiuwu Basin is available, literature value is taken with a range from $3,000 \mathrm{~m}^{3}$ to $46,000 \mathrm{~m}^{3}$, having a uniform distribution (Table 1). Then total amount of water required to develop shale gas in the "sweet spot" area is estimated by multiplying the number of horizontal wells by water consumption per horizontal well. The Monte Carlo method was used to generate 40,000 realizations of water consumption per horizontal well and number of horizontal wells. Total water demand was estimated at a range of $2.45 \times 10^{6} \mathrm{~m}^{3}$ to $1.99 \times 10^{8} \mathrm{~m}^{3}$ with a likely value (P50) of $5.33 \times 10^{7} \mathrm{~m}^{3}$. Apparently, the likely water demand (P50) for drilling and fracturing horizontal wells to develop shale gas in the "sweet spot" area is approximately $4 \%$ of the yearly agricultural use, or about $2 \%$ of the total annual water use in Jiujiang. Statistical analysis suggests that the maximum amount of water was estimated at $1.99 \times 10^{8} \mathrm{~m}^{3}$, approximately $7.5 \%$ of total annual water use in Jiujiang, or $14.3 \%$ of yearly agricultural use.

Jiangxi province aims to achieve a gas production rate of $3 \times 10^{8} \mathrm{~m}^{3} / \mathrm{y}$ at the Xiuwu Basin by 2020 [33]. A total number of horizontal wells could be estimated by dividing the planned gas production rate by the gas production rate of a single well simulated with the SRV method. A 
total of 2 to 560 horizontal wells are needed to achieve the planned gas production rate. With Monte Carlo simulations, water demand for drilling and fracturing these horizontal wells is estimated to be from $6.04 \times 10^{3} \mathrm{~m}^{3}$ to $2.57 \times 10^{7} \mathrm{~m}^{3}$ with a likely value (P50) of $5.37 \times 10^{6} \mathrm{~m}^{3}$.The likely water demand (P50) is even less than the yearly landscape use in Jiujiang (Table 4). The maximum water demand for gas production is only slightly higher than the city's yearly landscape, stock, or municipal use. Development of shale gas resources at the Xiuwu Basin will not likely impose stress on the regional water system. Note, however, that water demand for horizontal well drilling and hydraulic fracturing may lead to temporary problems in local water systems.

\subsection{Discussion on environmental impacts}

Reducing greenhouse gas emissions, especially $\mathrm{CO}_{2}$, from coal-burning power plants is one of the motivations for China's striving to develop shale gas resources. Assuming that 1 cubic meter of shale gas can provide $37 \mathrm{MJ}$ heat and $1 \mathrm{~kg}$ of coal can provide $24 \mathrm{MJ}$ heat, then shale gas produced from the "sweet spot" area can replace coal of $1.27 \times 10^{9}$ t. Assuming $57 \mathrm{~g} \mathrm{CO}_{2} \mathrm{e} / \mathrm{MJ}$ for combustion of shale gas and $105 \mathrm{~g} \mathrm{CO}_{2} \mathrm{e} / \mathrm{MJ}$ for coal combustion [44], burning shale gas produced from the "sweet spot" area will emit $1740 \mathrm{Mt}$ of $\mathrm{CO}_{2}$ much less than burning coal that will emit $3.20 \times 10^{6} \mathrm{Mt}$ of $\mathrm{CO}_{2}$. Obviously, a significant amount of $\mathrm{CO}_{2}$ emission can be reduced by switching from coal to shale gas as an energy source. In addition, replacing coal with shale gas to fuel electric power plants can also reduce emission of other hazardous gases such as NOx and $\mathrm{SO}_{2}[10,45]$ and toxic elements such as arsenic and mercury [46] into the atmosphere, mitigating the currently serious air pollution in China.

Despite potential benefits for energy use and reduction of greenhouse gas emissions, shale

gas development may also likely come with some environmental issues [1, 34, 47-50]. One 
critical issue is potential risk to ecosystems of inappropriate disposal and treatment of flow back wastewater containing brines, heavy metals, radionuclides, methane, and organic pollutants. The Xiuwu Basin is located in the watershed of Poyang Lake, which is the largest freshwater lake in China and contains extraordinary biodiversity. Discharge of the flowback wastewater from shale gas development without proper treatment and careful monitoring could potentially harm the ecosystem of Poyang Lake. U.S. experiences with regulation of hydraulic fracturing can be learned and practiced for the future development of shale gas resources at the Xiuwu Basin to avoid likely environmental risks. However, it should also be noted that risks of shale gas development on environments can vary from local to regional levels. A comprehensive, transparent, watershed-based research and management approach with data shared publicly is recommended for determining whether ecological systems are at risk from hydraulic fracturing operations $[48,51]$.

\section{Conclusions and recommendations}

This study develops a probabilistic framework by integrating the Monte Carlo method with a numerical model of shale gas transport in a horizontal well to assess likely shale gas production at the Xiuwu Basin. The numerical model simulates transport of a single gas phase from the stimulated zone to the main fractures by considering diffusion and desorption of shale gas from the organics in shale. Total 40,000 realizations generated with the Monte Carlo method based on possible range and probability distribution of model parameters were simulated to assess shale gas resources at the Xiuwu Basin.

Statistical results suggest that the gas production rate of a single horizontal well decreases with time. After 30 years, gas production rate decreases to a likely value of $1.44 \times 10^{4} \mathrm{~m}^{3} / \mathrm{d}$. Cumulative gas production from a single horizontal well after 30 years was estimated at a likely 
value of $3.50 \times 10^{8} \mathrm{~m}^{3}$. Sensitivity analysis indicates that the four most sensitive parameters to gas production rate and cumulative gas production are the relative volume occupied by kerogen in bulk volume of rock $\left(\mathrm{S}_{\mathrm{k}}\right)$, gas desorption rate $\left(\mathrm{C}_{\mathrm{f}}\right)$, number of stages $(\mathrm{N})$, and permeability of the stimulated zone (К). Probabilistic analysis suggests that total gas production at the "sweet spot" delineated by Pang et al.[29] at the Xiuwu Basin is estimated at a range of $1.13 \times 10^{10} \mathrm{~m}^{3}$ to $1.76 \times 10^{13} \mathrm{~m}^{3}$ with a likely value of $8.24 \times 10^{11} \mathrm{~m}^{3}$ which is higher than $2.92 \times 10^{11} \mathrm{~m}^{3}$ estimated with the deterministic volumetric method reported in [29]. The modeling results confirm that the goal to achieve shale gas production of $3 \times 10^{8} \mathrm{~m}^{3} / \mathrm{y}$ by 2020 [33] at the Xiuwu Basin is achievable.

China suffers shortage of water resources in most areas. Shale gas development requires a significant amount of water. Our study shows that water demand for shale gas production with hydraulic fracturing at the Xiuwuis approximately $4 \%$ of the yearly agricultural use, making up approximately $2 \%$ of the total annual water use in the Jiujiang. Even for a worst scenario, water demand is about $1.99 \times 10^{8} \mathrm{~m}^{3}$, approximately $7.5 \%$ of total annual water use in the Jiujiang or $14.3 \%$ of yearly agricultural use. Note that such prediction of water demand for shale gas development is on the basis of a regional scale water system. Horizontal well drilling and hydraulic fracturing may lead to temporary problems in local areas.

The modeling results of shale gas production and water demand predicted in this study can be integrated into an economic model, further providing guidance to design reasonable and practical strategies and optimize well drillings. This study also suggests that shale gas production at the study area depends on mainly the relative volume occupied by kerogen in bulk volume of rock, gas desorption rate, and permeability of the stimulated zone. Further studies to obtain good measurements of those parameters could improve assessment of shale gas resources. The 
modeling results could also be used by local governments to address public concerns on environmental issues, particularly shortage in water supplies. The probabilistic framework for assessing gas production and water demand developed in this study can also be applied to other shale gas reservoirs, especially those with limited production data. Note that predictions about shale gas production could be further improved if actual production data were made available to constrain uncertainties in the model parameters listed in Table 3.

\section{FIGURES}

Figure 1. Location of Xiuwu Basin. Red dot in inset indicates location of study area in China. Dash line is boundary of Xiuwu Basin. Black solid lines with numbers represent thickness of Wangyinpu Formation. Purple lines with numbers are contours of TOC content in shale. Yellow area is "sweet spot" at Wangyinpu Formation [29].

Figure 2. Schematics of (a) horizontal well drilled into shale and stimulated zone, and (b) 1D model domain between major fracture and zero flow boundary located at half-distance of two adjacent major fractures. Modified from [27].

Figure 3. Plots of (a) modeled gas production rate, and (b) cumulative gas production from a single horizontal well. Gray shaded areas are simulated results of 40,000 realizations over 30 years.

Figure 4. Bar plots of (a) local relative sensitivity for well production rate, (b) local relative sensitivity for cumulative well production, (c) Sobol global sensitivity indices for well production rate, and (d) Sobol indices for cumulative well production after 30 years.

Figure 5. Local relative sensitivity of gas production rate and cumulative production to model parameters over a 30-year time period. P1 to P12 represent model parameters, which are listed in Table 3.

Figure 6. Sobol's sensitivity indices of gas production rate and cumulative production to model parameters over a 30-year time period. P1 to P12 represent model parameters, which are listed in Table 3.

Figure 7. Plots of (a) precipitation, surface water, and groundwater resource; (b) surface water and groundwater supplied; and (c) percentage of yearly water usage by agriculture, industry, 
domestic, stock, municipal, and landscape from 2008 to 2013. SW = surface water; GW = groundwater; $\mathrm{PR}=$ precipitation .

\section{TABLES}

Table 1. Summary of water use for a single horizontal well fracturing reported in literature

Table 2. Characteristics of Wangyinpu Formation at Xiuwu Basin in literature

Table 3. Uncertain parameters with range, mean, standard deviation, and probability distribution function

Table 4. Statistics of well production rate, cumulative production, and total production of natural gas in Wangyinpu Formation at Xiuwu Basin, and predicted water demand for horizontal well drilling and fracturing

\section{ACKNOWLEDGMENTS}

This study has been funded by Jiangxi province as a key project in Achievements in Science and Technology through the project of Assessment of Shale Gas Resources in Jiangxi Province and Determination of Key Factors for Exploration (Project \# 20124ABE02104) and by Chinese National Science Foundation through the project of Migration of hazardous elements caused by coal mining and potential impacts on environments (Project \#41173115).We also thank Stephanie Jones from Bureau of Economic Geology, The University of Texas at Austin, who edited the manuscript. The authors want to thank for the reviewers and Dr. Jinyue Yan, the Chief-in-editor of Applied Energy for their constructive comments and suggestions for greatly improving this manuscript.

\section{REFERENCES}

[1] Vidic RD, Brantley SL, Vandenbossche JM, Yoxtheimer D, Abad JD. Impact of Shale Gas Development on Regional Water Quality. Science. 2013;340.

[2] Yuan J, Luo D, Feng L. A review of the technical and economic evaluation techniques for shale gas development. Applied Energy. 2015;148:49-65.

[3] Aguilera RF. The role of natural gas in a low carbon Asia Pacific. Applied Energy. 2014;113:1795-800.

[4] Weijermars R. Shale gas technology innovation rate impact on economic Base Case - Scenario model benchmarks. Applied Energy. 2015;139:398-407.

[5] McGlade C, Speirs J, Sorrell S. Unconventional gas - A review of regional and global resource estimates. Energy. 2013;55:571-84.

[6] Arora V, Cai Y. U.S. natural gas exports and their global impacts. Applied Energy. 2014;120:95-103. 
[7] Patzek TW, Male F, Marder M. Gas production in the Barnett Shale obeys a simple scaling theory. Proceedings of the National Academy of Sciences. 2013;110:19731-6.

[8] EIA. Technically recoverable shale oil and shale gas resources: an assessment of 137 shale formations in 41 countries outside the united states. Washington, DC2013. p. 730.

[9] Tollefson J. China slow to tap shale-gas bonanza. Nature. 2013;494:294.

[10] Chang $Y$, Huang R, Masanet E. The energy, water, and air pollution implications of tapping China's shale gas reserves. Resources, Conservation and Recycling. 2014;91:100-8.

[11] Hu D, Xu S. Opportunity, challenges and policy choices for China on the development of shale gas. Energy Policy. 2013;60:21-6.

[12] Yang H, Huang X, Yang Q, Tu J, Li S, Yang D, et al. Water Requirements for Shale Gas Fracking in Fuling, Chongqing, Southwest China. Energy Procedia. 2015;76:106-12.

[13] Aguilera RF, Ripple RD. Using size distribution analysis to forecast natural gas resources in Asia Pacific. Applied Energy. 2011;88:4607-20.

[14] Wilson A. Probabilistic and Deterministic Methods: Applicability in Unconventional Reservoirs. Journal of Petroleum Technology. 2013;65:86-9.

[15] Allan PD. Stochastic Analysis of Resource Plays: Maximizing Portfolio Value and Mitigating Risks. SPE Economics \& Management. 2011;3:141-8.

[16] Salazar J, McVay DA, Lee WJ. Development of an Improved Methodology to Assess Potential Unconventional Gas Resources. Natural Resources Research. 2010;19:253-68.

[17] Kim J-S, Shin H-J, Lim J-S. Application of a Probabilistic Method to the Forecast of Production Rate Using a Decline Curve Analysis of Shale Gas Play. The Twenty-fourth International Ocean and Polar Engineering Conference. Busan, Korea: International Society of Offshore and Polar Engineers; 2014. p. 100-5.

[18] Cronquist C. Reserves and Probabilities: Synergism or Anachronism? (includes associated papers 24318, 24404, 24405 and 24413 ). Journal of Petroleum Technology. 1991;43:1258 - 64.

[19] Cheng Y, Wang Y, McVay D, Lee WJ. Practical Application of a Probabilistic Approach to Estimate Reserves Using Production Decline Data. SPE Economics \& Management. 2010;2:19 - 31.

[20] Dong Z, Holditch S, McVay D. Resource Evaluation for Shale Gas Reservoirs. SPE Economics \& Management. 2013;5:5-16.

[21] Knudsen BR, Foss B. Shut-in based production optimization of shale-gas systems. Computers \& Chemical Engineering. 2013;58:54-67.

[22] Lee WJ, Sidle R. Gas-Reserves Estimation in Resource Plays. SPE Economics \& Management. 2010;62:86-91.

[23] Brown M, Ozkan E, Raghavan R, Kazemi H. Practical Solutions for Pressure-Transient Responses of Fractured Horizontal Wells in Unconventional Shale Reservoirs. SPE Reservoir Evaluation \& Engineering. 2011;14:663 - 76.

[24] Cheng Y, Lee WJ, McVay DA. Improving Reserves Estimates From Decline-Curve Analysis of Tight and Multilayer Gas Wells. SPE Res Eval \& Eng. 2008;11:912-20.

[25] Nobakht M, Mattar L, Moghadam S, Anderson DM. Simplified Yet Rigorous Forecasting of Tight/Shale Gas Production in Linear Flow. J Can Pet Technol. 2012;51:476 - 86.

[26] Wilson A. A Critical View of the Current State of Reservoir Modeling of Shale Assets. Journal of Petroleum Technology. 2014;66:98 - 101.

[27] Silin D, Kneafsey TJ. Shale Gas: Nanometer-Scale Observations and Well Modelling. J Can Pet Technol. 2012;51:464 - 75.

[28] Xia X, Hu X, Wang C. Shale gas accumulation condition and potential in Lower Cambrian in northwestern Jiangxi. Speical oil and gas reserviors. 2013;20:35-9.

[29] Pang F, Bao S, Ren S, Li S, Tong C, Zeng L. Shale gas accumulation conditions and favorable areas of the loweer Cambrian in Xiuwu Basin. Journal of northeast petroleum university. 2014;38:23-31. 
[30] Liu W, Tian J, Lin X, Shi J, Yang C, Peng S. Characteristics and significance of mineral compositions in lower Cambrian black shale from Xiuwu Basin, Jiangxi, China. Journal of Chengdu University of Technology (Science \& Technology Edition). 2015;42:90-7.

[31] Qin W, Han Q, Wang J. Shale gas reservioring condition analysis in Xiuwu basin. Enenrgy research and management. 2013:46-9.

[32] Qi X, Yi X, Wang B, Zhang S. Shale gas exploration prospect of lower Cambrian Wangyinpu Formation in Ruichangb-Dean area of Jiangxi Province. Energy Research and Mangement. 2014:55-8. [33] Jiangxi Energy Bureau. 10-year Plan for shale gasexploitation and development in Jiangxi Province, China. Jiangxi, China: Jiangxi Energy Bureau 2011. p. 120.

[34] Kargbo DM, Wilhelm RG, Campbell DJ. Natural Gas Plays in the Marcellus Shale: Challenges and Potential Opportunities. Environ Sci Tech. 2010;44:5679-84.

[35] Murray KE. State-Scale Perspective on Water Use and Production Associated with Oil and Gas Operations, Oklahoma, U.S. Environ Sci Tech. 2013;47:4918-25.

[36] Nicot J-P, Scanlon BR. Water Use for Shale-Gas Production in Texas, U.S. Environ Sci Tech. 2012;46:3580-6.

[37] Yang C, Romanak K, Hovorka S, Triveno R. Modeling $\mathrm{CO}_{2}$ release experiment in the shallow subsurface and sensitivity analysis. Environ Eng Geosci. 2013;19:207-20.

[38] Samper J, Yang C, Naves A, Yllera A, Hernández A, Molinero J, et al. A fully 3-D anisotropic numerical model of the DI-B in situ diffusion experiment in the Opalinus clay formation. Phys Chem Earth, Parts A/B/C. 2006;31:531-40.

[39] Saltelli A, Annoni P, Azzini I, Campolongo F, Ratto M, Tarantola S. Variance based sensitivity analysis of model output. Design and estimator for the total sensitivity index. Comput Phys Commun. 2010;181:259-70.

[40] Saltelli A. Making best use of model evaluations to compute sensitivity indices. Comput Phys Commun. 2002;145:280-97.

[41] Ezisi I, Hale BW, Watson MC, Heinze L. Assessment of Probabilistic Parameters for Barnett Shale Recoverable Volumes. SPE Hydrocarbon Economics and Evaluation Symposium. Calgary, Alberta, Canada: Society of Petroleum Engineers; 2012.

[42] Ground Water Protection Council. Modern shale gas development in the United States: a primer. Oklahoma City, Oklahoma Ground Water Protection Council; 2009.

[43] Water resource bureau of Jiangxi Province. Jiangxi water resource bullitin (2008-2013). In: Zhu L, Fu G, Tan G, editors. Jiangxi water resource bullitin. Nanchang, Jiangxi: Water resource bureau of Jiangxi Province; 2014.

[44] Burnham A, Han J, Clark CE, Wang M, Dunn JB, Palou-Rivera I. Life-Cycle Greenhouse Gas Emissions of Shale Gas, Natural Gas, Coal, and Petroleum. Environ Sci Tech. 2012;46:619-27.

[45] Chang Y, Huang R, Ries RJ, Masanet E. Shale-to-well energy use and air pollutant emissions of shale gas production in China. Applied Energy. 2014;125:147-57.

[46] Tian HZ, Wang Y, Xue ZG, Cheng K, Qu YP, Chai FH, et al. Trend and characteristics of atmospheric emissions of $\mathrm{Hg}$, As, and Se from coal combustion in China, 1980-2007. Atmos Chem Phys.

2010;10:11905-19.

[47] Lavoie D, Rivard C, Lefebvre R, Séjourné S, Thériault R, Duchesne MJ, et al. The Utica Shale and gas play in southern Quebec: Geological and hydrogeological syntheses and methodological approaches to groundwater risk evaluation. International Journal of Coal Geology. 2014;126:77-91.

[48] Brantley SL, Yoxtheimer D, Arjmand S, Grieve P, Vidic R, Pollak J, et al. Water resource impacts during unconventional shale gas development: The Pennsylvania experience. International Journal of Coal Geology. 2014;126:140-56.

[49] Stamford L, Azapagic A. Life cycle environmental impacts of UK shale gas. Applied Energy. 2014;134:506-18. 
[50] Whitmarsh L, Nash N, Upham P, Lloyd A, Verdon JP, Kendall JM. UK public perceptions of shale gas hydraulic fracturing: The role of audience, message and contextual factors on risk perceptions and policy support. Applied Energy. 2015;160:419-30.

[51] Burton GA, Basu N, Ellis BR, Kapo KE, Entrekin S, Nadelhoffer K. Hydraulic "Fracking": Are surface water impacts an ecological concern? Environ Toxicol Chem. 2014;33:1679-89.

[52] Goodwin S, Carlson K, Knox K, Douglas C, Rein L. Water Intensity Assessment of Shale Gas Resources in the Wattenberg Field in Northeastern Colorado. Environ Sci Tech. 2014;48:5991-5.

[53] Lutz BD, Lewis AN, Doyle MW. Generation, transport, and disposal of wastewater associated with Marcellus Shale gas development. Water Resour Res. 2013;49:647-56.

[54] Liu Q. An Assessment of Water Impact in Shale Gas Development: A Case Study of the Horn River Basin. Waterloo, Ontario, Canada: University of Waterloo; 2014.

[55] Johnson EG, Jonson LA. Hydraulic fracture water usage in northeast British Columbia: locations, volumes and trends. Geoscience Reports. British Columbia: British Columbia Ministry of Energy and Mines; 2012. p. 41-63.

Table 1. Summary of water use for a single horizontal well fracturing reported in literature

Water consumption for a horizontal well Data Source

China's first shale gas horizontal well (Wei 201-H1)

[10] $25000 \mathrm{~m}^{3}$ per well

Fuling Basin, China

$3,096 \mathrm{~m}^{3}$ to $46,149 \mathrm{~m}^{3}$; mean 27,490 ; standard deviation: $28,800 \mathrm{~m}^{3}$

Texas, USA

Barnett Shale: $2,900 \mathrm{~m}^{3}$ to $20,700 \mathrm{~m}^{3}$ ( $5^{\text {th }}$ to $95^{\text {th }}$ percentiles) with median of $10,600 \mathrm{~m}^{3}$

Haynesville Shale: $2,700 \mathrm{~m}^{3}$ to $28,100 \mathrm{~m}^{3}$ ( $5^{\text {th }}$ to $95^{\text {th }}$ percentiles $)$ with median of

$21,500 \mathrm{~m}^{3}$

Eagle Ford Shale: $4,600 \mathrm{~m}^{3}$ to $33,900 \mathrm{~m}^{3}\left(5^{\text {th }}\right.$ to $95^{\text {th }}$ percentiles $)$ with median of

$16,100 \mathrm{~m}^{3}$

Wattenberg Field, Northeastern Colorado, USA

Niobrara Shale: $5,300 \mathrm{~m}^{3}$ to $28,400 \mathrm{~m}^{3}\left(10^{\text {th }}\right.$ to $90^{\text {th }}$ percentiles $)$ with median of $11,400 \mathrm{~m}^{3}$

Oklahoma, USA

Woodford Shale: $11,400 \mathrm{~m}^{3}$ to $22,300 \mathrm{~m}^{3}$ ( $25^{\text {th }}$ to $75^{\text {th }}$ quartiles) with median of $15,800 \mathrm{~m}^{3}$

Mississippian Shale: $5,000 \mathrm{~m}^{3}$ to $8,900 \mathrm{~m}^{3}\left(25^{\text {th }}\right.$ to $75^{\text {th }}$ quartiles $)$ with median of $70,00 \mathrm{~m}^{3}$

Desmoinesian Shale: $5,400 \mathrm{~m}^{3}$ to $10,700 \mathrm{~m}^{3}$ ( $25^{\text {th }}$ to $75^{\text {th }}$ quartiles) with median of $7,600 \mathrm{~m}^{3}$

Pennsylvania, USA

Marcellus Shale: $7,700 \mathrm{~m}^{3}$ to $38,000 \mathrm{~m}^{3}(<2010)$; $11,500 \mathrm{~m}^{3}$ to $19,000 \mathrm{~m}^{3}$ (2008-

2011)

Horn River Basin, British Columbia, Canada

Average: 4,000 $\mathrm{m}^{3}$; maximum: $15,000 \mathrm{~m}^{3}$

British Columbia, Canada 
Montney: $1,900 \mathrm{~m}^{3}$ to $7,800 \mathrm{~m}^{3}$; DoigHospate: $4,800 \mathrm{~m}^{3}$; Gething: $400 \mathrm{~m}^{3}$ to $10,000 \mathrm{~m}^{3}$;

Muskwa-Otter Park: $34,900 \mathrm{~m}^{3}$; Evie: $19,500 \mathrm{~m}^{3}$; Cadomin: 8,800 $\mathrm{m}^{3}$;

Nikanassin: $21,000 \mathrm{~m}^{3}$ to $26,000 \mathrm{~m}^{3}$. 
Table 2. Characteristics of Wangyinpu Formation at Xiuwu Basin in literature

\begin{tabular}{|c|c|c|c|c|c|}
\hline Data sources & [30] & [29] & [32] & [28] & [31] \\
\hline $\begin{array}{l}\text { Depth of shale } \\
\text { reservoir(m) }\end{array}$ & $\mathrm{n} / \mathrm{a}$ & 660-840 (pilot well) & $20-3,500$ & $1,500-350$ & $\mathrm{n} / \mathrm{a}$ \\
\hline Thickness (m) & Outcrops: 45.2 & Outcrops: 100-200 & $\begin{array}{l}\text { 50-250, average: } \\
110\end{array}$ & $150-400$ & $\begin{array}{l}\text { 59-143, } \\
\text { average:120 }\end{array}$ \\
\hline TOC (\%) & $\mathrm{n} / \mathrm{a}$ & $\begin{array}{l}\text { Outcrops: } 2 \%-15.5 \% \text {, } \\
\text { average: } 8.4 \% \\
\text { Cores from reservoir: } 3.3 \% \\
-14.2 \%(9.2 \%)\end{array}$ & $\begin{array}{l}\text { Outcrops: } 2.35 \%- \\
4.54 \%\end{array}$ & $\begin{array}{l}\text { Outcrops: } 1.37 \%-4.93 \% \text {, } \\
\text { average: } 2.87 \%\end{array}$ & $\begin{array}{l}\text { Outcrops: lowest: } \\
3.87 \% \text {, average: } \\
4.5 \%\end{array}$ \\
\hline Ro (\%) & $2.5 \%-3.3 \%$, average: $2.97 \%$ & $2.0 \%-4.5 \%$, average:3.2\% & $2.36 \%-4.21 \%$ & $\begin{array}{l}2.56 \%-3.39 \% \\
\text { average: } 2.78 \%\end{array}$ & average:3.94\% \\
\hline Types of organics & $\mathrm{n} / \mathrm{a}$ & $\mathrm{n} / \mathrm{a}$ & $\mathrm{n} / \mathrm{a}$ & II -III & I \\
\hline Mineralogy & $\begin{array}{l}\text { Samples collected from } \\
\text { outcrops; } X \text {-ray analysis } \\
\text { indicates that brittle } \\
\text { minerals are mainly quartz } \\
(37.7 \% \text { to } 72.1 \% \text { with } \\
\text { average of } 58.6 \%) \text {; clay } \\
\text { minerals ( } 11.5 \% \text { to } 41 \% \text { with } \\
\text { average of } 25.4 \%) \text {; feldspars } \\
(2.5 \%) \text {; and pyrite }(4.7 \%)\end{array}$ & $\begin{array}{l}\text { Brittle minerals are mainly } \\
\text { quartz, } 40 \%-80 \% \text {; clay } \\
\text { minerals: } 6 \%-45 \%\end{array}$ & $\begin{array}{l}\text { Samples collected } \\
\text { from outcrops; } X \text { - } \\
\text { ray analysis } \\
\text { indicates that brittle } \\
\text { minerals are } 53.3 \% \\
\text { to } 69.4 \% \text {, which is } \\
\text { mainly quartz } \\
\text { ( } 43.5 \% \text { to } 56.4 \%) \text {; } \\
\text { clay minerals }(29.8 \% \\
\text { to } 46.5 \% \text { ) }\end{array}$ & $\begin{array}{l}\text { Samples collected from } \\
\text { outcrops; X-ray analysis } \\
\text { indicates that brittle } \\
\text { minerals are } 56.7 \% \text { to } 79.7 \% \\
\text { (average of } 66.7 \% \text { ), mainly } \\
\text { quartz (average of } \\
61.9 \% \text { ), with average } \\
\text { feldspars of } 4.8 \% \text {; clay } \\
\text { minerals ( } 15.4 \% \text { to } 29.3 \% \\
\text { with average of } 23.9 \% \text { ) }\end{array}$ & $\begin{array}{l}\text { Samples collected } \\
\text { from outcrops; } X \text { - } \\
\text { ray analysis } \\
\text { indicates that brittle } \\
\text { minerals are mainly } \\
\text { quartz ( } 65.7 \% \text { to } \\
79.7 \% \text { ) }\end{array}$ \\
\hline Permeability $\times 10^{-3} \mu \mathrm{m}$ & $\mathrm{n} / \mathrm{a}$ & (0.004-0.2), average: 0.022 & $\mathrm{n} / \mathrm{a}$ & $\begin{array}{l}(0.00050-0.00120) \\
\text { average: } 0.00062\end{array}$ & $0.0042-0.0085$ \\
\hline $\begin{array}{l}\text { Porosity and pore } \\
\text { characteristics }\end{array}$ & $\mathrm{n} / \mathrm{a}$ & $1 \%-4 \%(2.6 \%)$ & $\mathrm{n} / \mathrm{a}$ & $\begin{array}{l}1.06 \%-7.86 \% \text {, average: } \\
2.86 \%\end{array}$ & $2.1-2.3$ \\
\hline Desorption/adsorption & $\mathrm{n} / \mathrm{a}$ & $\begin{array}{l}\text { Langmuir p:1.75 MPa, } 7.91 \\
\mathrm{m3} / \mathrm{t} \text {; pilot well: } 0.10-0.38 \\
\mathrm{m3} / \mathrm{t}\end{array}$ & $\mathrm{n} / \mathrm{a}$ & $\begin{array}{l}\text { Langmuir p:10 MPa, } 2.0 \\
\mathrm{~m} 3 / \mathrm{t}\end{array}$ & $\mathrm{n} / \mathrm{a}$ \\
\hline Temperature & $\mathrm{n} / \mathrm{a}$ & $\mathrm{n} / \mathrm{a}$ & $\mathrm{n} / \mathrm{a}$ & $\mathrm{n} / \mathrm{a}$ & $90-112.5^{\circ} \mathrm{C}$ \\
\hline $\begin{array}{l}\text { Estimated resources }\left(10^{8}\right. \\
\left.\mathrm{m}^{3}\right)\end{array}$ & $\mathrm{n} / \mathrm{a}$ & $\sim 2,923$ for whole basin & $\mathrm{n} / \mathrm{a}$ & $\begin{array}{l}26,000 \text { for northwest of } \\
\text { Jiangxi province(including } \\
\text { basin) }\end{array}$ & $\mathrm{n} / \mathrm{a}$ \\
\hline
\end{tabular}


2 Table 3. Uncertain parameters with range, mean, standard deviation, and probability distribution 3 function

\begin{tabular}{|c|c|c|c|c|c|c|}
\hline$\#$ & Parameter & PDF $^{1}$ & Min & Max & Mean & $\begin{array}{l}\text { Standard } \\
\text { deviation }\end{array}$ \\
\hline P1 & Area of fracture face $\left(S, \mathrm{~m}^{2}\right)$ & Uniform & 6,903 & 13,530 & 10,221 & 1,920 \\
\hline $\mathbf{P 2}$ & $\begin{array}{l}\text { Half distance between two } \\
\text { adjacent major fractures }\left(D_{f},\right. \\
m)\end{array}$ & Uniform & 23 & 152 & 31.5 & 12 \\
\hline P3 & $\begin{array}{l}\text { Number of stages ( } N \text {, fractures } \\
\text { per well) }\end{array}$ & Uniform & 10 & 40 & 25 & 9 \\
\hline P4 & $\begin{array}{l}\text { Permeability of stimulated } \\
\text { zone }\left(\kappa, \mathrm{m}^{2}\right)\end{array}$ & Lognormal & $5 \times 10^{-12}$ & $500 \times 10^{-12}$ & $3 \times 10^{-10}$ & $1.5 \times 10^{-10}$ \\
\hline P5 & Dynamic viscosity ( $\mu$, Pa.d) & Lognormal & 0.965 & 1.062 & 1.00 & 0.414 \\
\hline P6 & Porosity $(\phi,-)$ & Lognormal & 0.01 & 0.07 & 0.043 & 0.03 \\
\hline P7 & $\begin{array}{l}\text { Gas desorption rate }\left(c_{\mathrm{f}}\right. \\
\left.\mathrm{m}^{3} /(\mathrm{kg} \cdot \mathrm{Pa})\right)\end{array}$ & Uniform & $2 \times 10^{-9}$ & $1 \times 10^{-7}$ & $5.1 \times 10^{-8}$ & $2.8 \times 10^{-8}$ \\
\hline P8 & $\begin{array}{l}\text { Relative volume occupied by } \\
\text { kerogen in bulk volume of rock } \\
\left(S_{k},-\right)\end{array}$ & Lognormal & 0.04 & 0.24 & 0.08 & 0.05 \\
\hline P9 & $\begin{array}{l}\text { Initial reservoir pressure }\left(\mathrm{P}_{\mathrm{i}},\right. \\
\mathrm{MPa})\end{array}$ & Uniform & 14.713 & 29.42 & 22.084 & 4.247 \\
\hline P10 & Pressure in well $\left(\mathrm{P}_{\mathrm{w}}, \mathrm{MPa}\right)$ & Uniform & 1.379 & 4.826 & 3.089 & 1.00 \\
\hline P11 & Reservoir temperature $\left(T,{ }^{\circ} \mathrm{C}\right)$ & Uniform & 55.5 & 93 & 74 & 11 \\
\hline P12 & Compressibility factor (Z, -) & Lognormal & 1.2 & 1.6 & 1.4 & 0.3 \\
\hline
\end{tabular}

$5 \quad$ PDF = probability distribution function

6

7

8

9

10

11 
Table 4. Statistics of well production rate, cumulative production, and total production of natural gas in Wangyinpu Formation at Xiuwu Basin area, and predicted water demand for horizontal well drilling and fracturing

\begin{tabular}{|c|c|c|c|c|c|c|c|c|c|c|c|c|}
\hline & Years & P5 & P10 & P25 & P50 & P75 & P90 & P95 & Mean & Std & Min & Max \\
\hline \multirow{3}{*}{$\begin{array}{l}\text { Well production rate of } \\
\text { single horizontal well } \\
\left(\mathbf{m}^{3} / \mathbf{d}\right)\end{array}$} & 5 & $1.05 \times 10^{4}$ & $1.43 \times 10^{4}$ & $2.34 \times 10^{4}$ & $4.06 \times 10^{4}$ & $6.84 \times 10^{4}$ & $1.06 \times 10^{5}$ & $1.35 \times 10^{5}$ & $5.26 \times 10^{4}$ & $4.28 \times 10^{4}$ & $1.47 \times 10^{3}$ & $7.61 \times 10^{5}$ \\
\hline & 15 & $5.11 \times 10^{3}$ & $7.26 \times 10^{3}$ & $1.25 \times 10^{4}$ & $2.22 \times 10^{4}$ & $3.80 \times 10^{4}$ & $5.95 \times 10^{4}$ & $7.63 \times 10^{4}$ & $2.91 \times 10^{4}$ & $2.44 \times 10^{4}$ & $2.86 \times 10^{2}$ & $4.41 \times 10^{5}$ \\
\hline & 30 & $2.48 \times 10^{3}$ & $3.98 \times 10^{3}$ & $7.67 \times 10^{3}$ & $1.44 \times 10^{4}$ & $2.53 \times 10^{4}$ & $4.00 \times 10^{4}$ & $5.18 \times 10^{4}$ & $1.91 \times 10^{4}$ & $1.68 \times 10^{4}$ & $5.54 \times 10^{1}$ & $3.12 \times 10^{5}$ \\
\hline \multirow{3}{*}{$\begin{array}{l}\text { Cumulative production } \\
\text { of single horizontal well } \\
\left(\mathbf{m}^{\mathbf{3}}\right)\end{array}$} & 5 & $3.88 \times 10^{7}$ & $5.24 \times 10^{7}$ & $8.53 \times 10^{7}$ & $1.47 \times 10^{8}$ & $2.48 \times 10^{8}$ & $3.84 \times 10^{8}$ & $4.89 \times 10^{8}$ & $1.91 \times 10^{8}$ & $1.55 \times 10^{8}$ & $5.41 \times 10^{6}$ & $2.74 \times 10^{9}$ \\
\hline & 15 & $6.56 \times 10^{7}$ & $8.90 \times 10^{7}$ & $1.46 \times 10^{8}$ & $2.53 \times 10^{8}$ & $4.27 \times 10^{8}$ & $6.63 \times 10^{8}$ & $8.43 \times 10^{8}$ & $3.28 \times 10^{8}$ & $2.67 \times 10^{8}$ & $9.05 \times 10^{6}$ & $4.77 \times 10^{9}$ \\
\hline & 30 & $8.87 \times 10^{7}$ & $1.21 \times 10^{8}$ & $2.01 \times 10^{8}$ & $3.50 \times 10^{8}$ & $5.93 \times 10^{8}$ & $9.22 \times 10^{8}$ & $1.18 \times 10^{9}$ & $4.56 \times 10^{8}$ & $3.74 \times 10^{8}$ & $1.06 \times 10^{7}$ & $6.78 \times 10^{9}$ \\
\hline $\begin{array}{l}\text { Total production in } \\
\text { "sweet spot" area }\left(\mathbf{m}^{\mathbf{3}}\right)\end{array}$ & 30 & $1.69 \times 10^{11}$ & $2.40 \times 10^{11}$ & $4.33 \times 10^{11}$ & $8.24 \times 10^{11}$ & $1.51 \times 10^{12}$ & $2.52 \times 10^{12}$ & $3.36 \times 10^{12}$ & $1.17 \times 10^{12}$ & $1.12 \times 10^{12}$ & $1.13 \times 10^{10}$ & $1.76 \times 10^{13}$ \\
\hline $\begin{array}{l}\text { Total amount of water } \\
\text { required for developing } \\
\text { shale gas resources at } \\
\text { "sweet spot" area (m3) }\end{array}$ & 30 & $1.06 \times 10^{7}$ & $1.53 \times 10^{7}$ & $2.89 \times 10^{7}$ & $5.33 \times 10^{7}$ & $8.97 \times 10^{7}$ & $1.27 \times 10^{8}$ & $1.47 \times 10^{8}$ & $6.29 \times 10^{7}$ & $4.23 \times 10^{7}$ & $2.45 \times 10^{6}$ & $1.99 \times 10^{8}$ \\
\hline $\begin{array}{l}\text { Total amount of water } \\
\text { required for planned } \\
\text { gas production rate } \\
\left(3 \times 10^{8} \mathrm{~m}^{3} / \mathrm{y}\right) \text { by } 2020 \\
\left(\mathrm{~m}^{3}\right)\end{array}$ & 5 & $4.64 \times 10^{5}$ & $9.04 \times 10^{5}$ & $2.26 \times 10^{6}$ & $5.37 \times 10^{6}$ & $1.03 \times 10^{7}$ & $1.55 \times 10^{7}$ & $1.83 \times 10^{7}$ & $6.88 \times 10^{6}$ & $5.64 \times 10^{6}$ & $6.04 \times 10^{3}$ & $2.57 \times 10^{7}$ \\
\hline
\end{tabular}


23 This Appendix contains 4 supplementary figures to the main text.

25 Figure A1. Comparison of general properties of 13 worldwide shale gas plays. 26 Xiuwu=Wangyinpu group at Xiuwu Basin in China; Permian= Permian shales in Lower Yangtze 27 region, Eastern China; LCambrian=Lower Cambrian shale in Northern Guizhou province, South 28 China; Antrim = Late Devonian Antrim shale in Michigan Basin; Ohio = Devonian Ohio shale in 29 Appalachian Basin; New Albany = Devonian-Mississippian New Albany shale in Illinois Basin; 30 Barnett $=$ Mississippian Barnett shale in Fort Worth Basin; Lewis $=$ Upper Cretaceous Lewis 31 shale in San Juan Basin; Fayetteville = Mississippian Fayetteville shale in Arkoma Basin; 32 Haynesville = Upper Jurassic Haynesville Formation in North Louisiana salt basin; Marcellus = 33 Devonian Marcellus shale in Appalachian Basin; Woodford = Devonian Woodford shale in 34 south-central Oklahoma; Devonian=Devonian-Mississippian strata in western Canada 35 sedimentary basin.

36 Figure A2. Histogram of well production rate after (a) 5 years, (b) 15 years, and (c) 30 years.

37 Figure A3. Histogram of cumulative production after (a) 5 years, (b) 15 years, and (c) 30 years.

38 Figure A4. Histogram of total gas production in the "sweet spot" area after 30 years. 
Figure captions

Figure 1. Location of Xiuwu Basin. Red dot in inset indicates location of study area in China. Dash line is boundary of Xiuwu Basin. Black solid lines with numbers represent thickness of Wangyinpu Formation. Purple lines with numbers are contours of TOC content in shale. Yellow area is "sweet spot" at Wangyinpu Formation [29].

Figure 2. Schematics of (a) horizontal well drilled into shale and stimulated zone, and (b) 1D model domain between major fracture and zero flow boundary located at half-distance of two adjacent major fractures. Modified from [27].

Figure 3. Plots of (a) modeled gas production rate, and (b) cumulative gas production from a single horizontal well. Gray shaded areas are simulated results of 40,000 realizations over 30 years.

Figure 4. Bar plots of (a) local relative sensitivity for well production rate, (b) local relative sensitivity for cumulative well production, (c) Sobol global sensitivity indices for well production rate, and (d)Sobol indices for cumulative well production after 30 years.

Figure 5. Local relative sensitivity of gas production rate and cumulative production to model parameters over a 30-year time period. P1 to P12 are model parameters listed in Table 3.

Figure 6. Sobol's sensitivity indices of gas production rate and cumulative production to model parameters over a 30-year time period. P1 to P12 are model parameters listed in Table 3.

Figure 7. Plots of (a) precipitation, surface water, and groundwater resource; (b) surface water and groundwater supplied; and (c) percentage of yearly water usage by agriculture, industry, domestic, stock, municipal, and landscape from 2008 to 2013. SW = surface water; GW = groundwater; $\mathrm{PR}=$ precipitation.

Figure A1. Comparison of general properties of 13 worldwide shale gas plays. Xiuwu=Wangyinpu group at Xiuwu Basin in China; Permian= Permian shales in Lower Yangtze region, Eastern China; LCambrian=Lower Cambrian shale in Northern Guizhou province, South 
China; Antrim = Late Devonian Antrim shale in Michigan Basin; Ohio = Devonian Ohio shale in Appalachian Basin; New Albany = Devonian-Mississippian New Albany shale in Illinois Basin; Barnett = Mississippian Barnett shale in Fort Worth Basin; Lewis = Upper Cretaceous Lewis shale in San Juan Basin; Fayetteville = Mississippian Fayetteville shale in Arkoma Basin; Haynesville = Upper Jurassic Haynesville Formation in North Louisiana salt basin; Marcellus = Devonian Marcellus shale in Appalachian Basin; Woodford = Devonian Woodford shale in south-central Oklahoma; Devonian=Devonian-Mississippian strata in western Canada sedimentary basin.

Figure A2. Histogram of well production rate after (a) 5 years, (b) 15 years, and (c) 30 years.

Figure A3. Histogram of cumulative production after (a) 5 years, (b) 15 years, and (c) 30 years.

Figure A4. Histogram of total gas production in the "sweet spot" area after 30 years. 


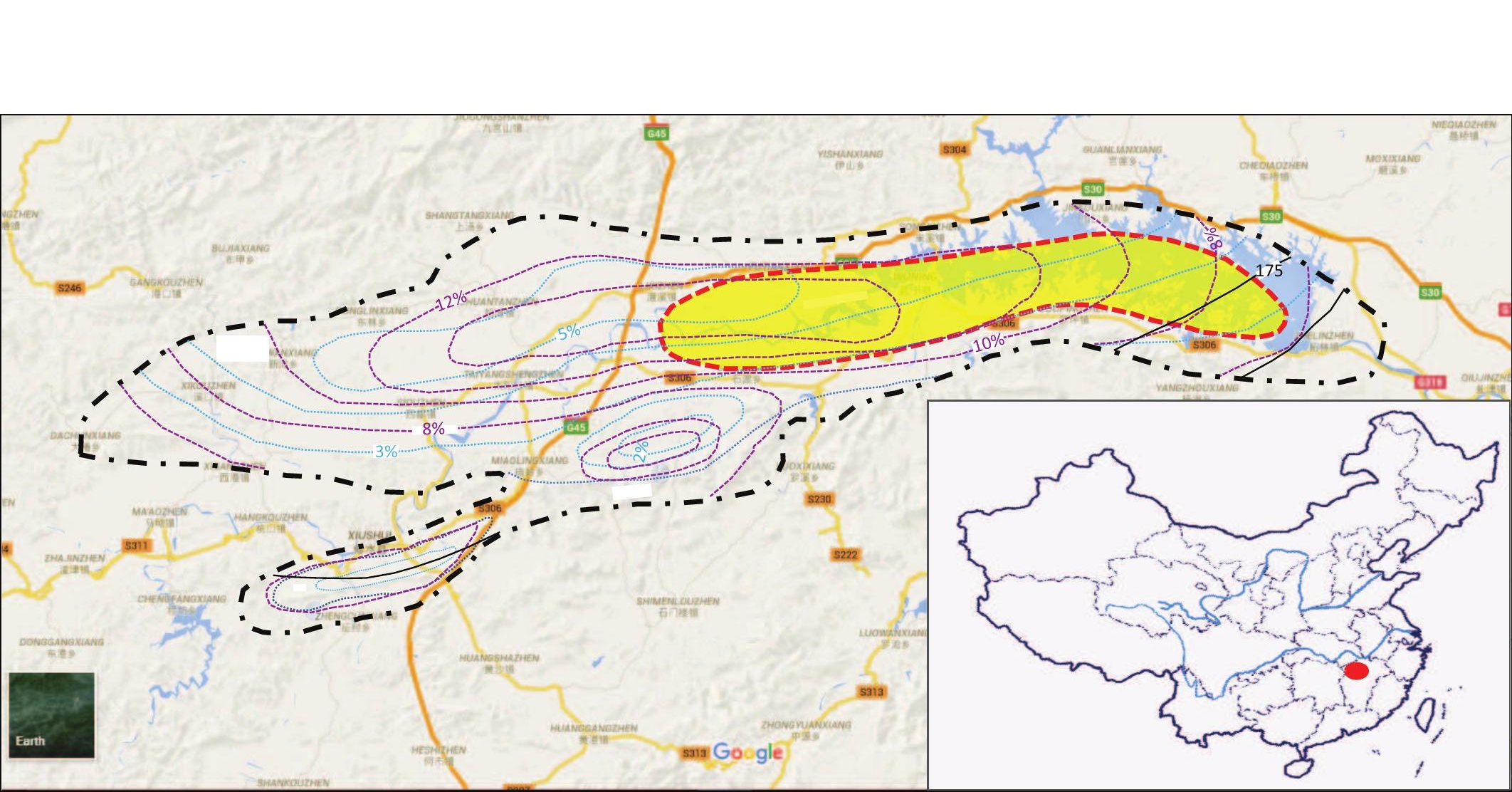

Figure 1

\section{Figure 1} (1)
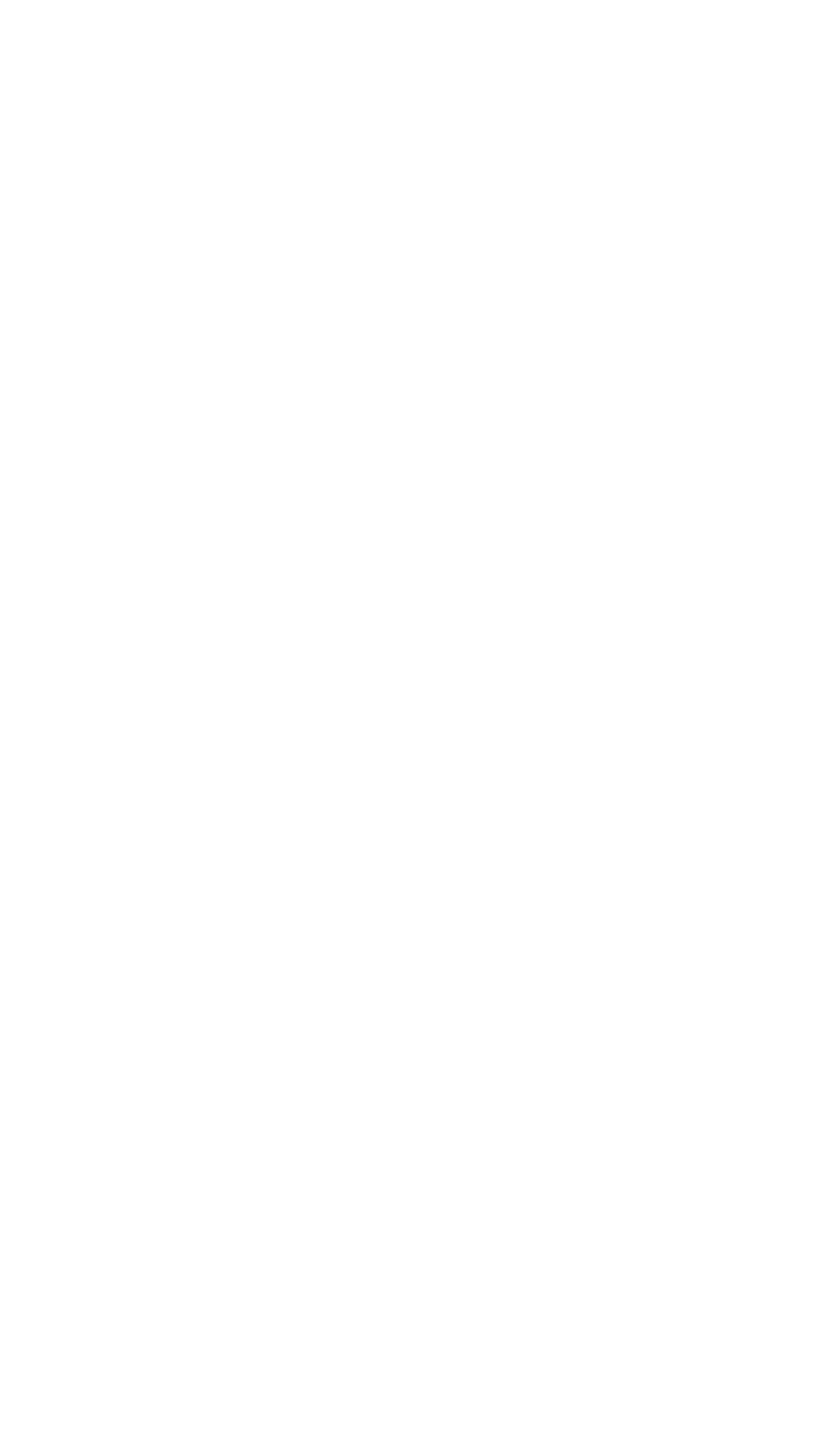
a)

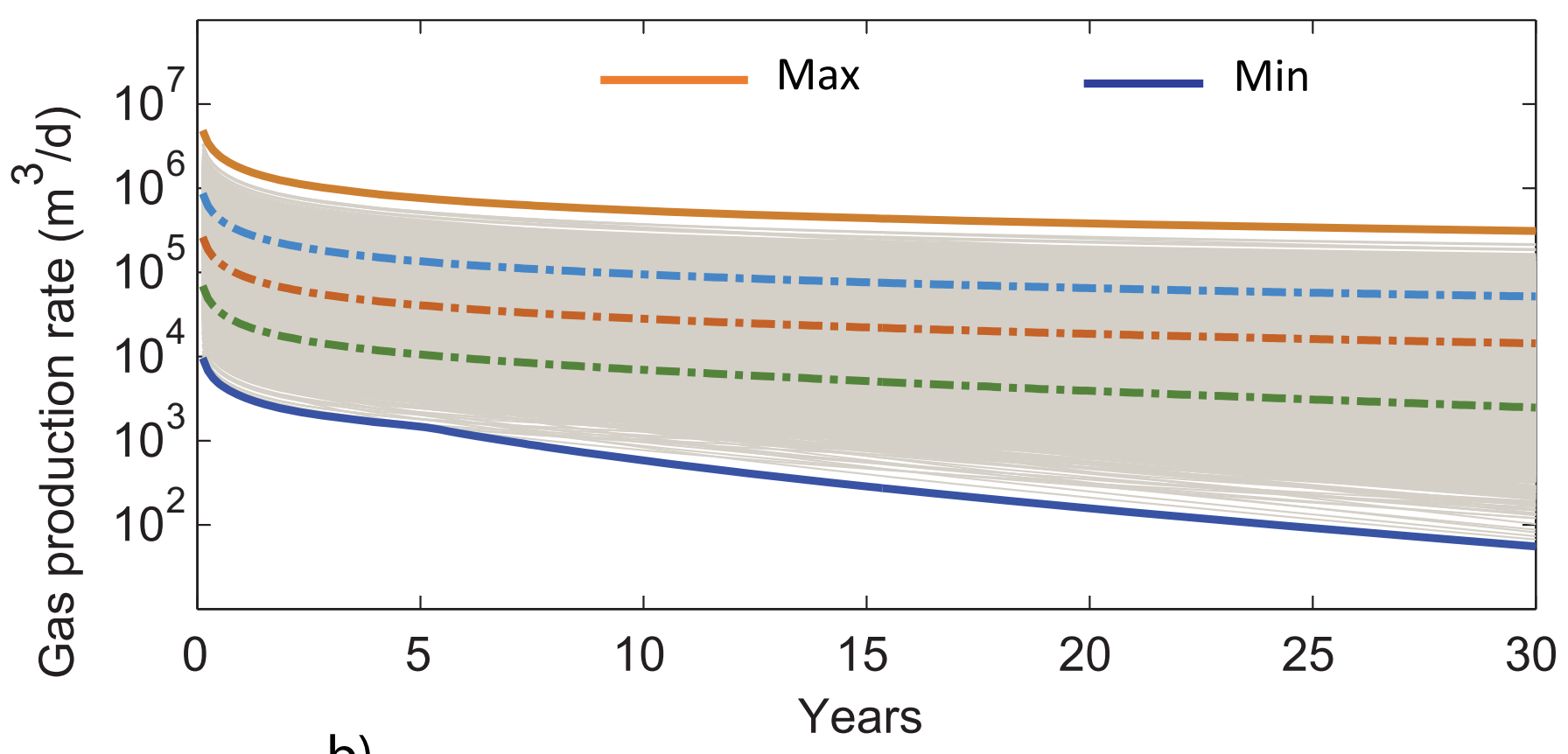

b)

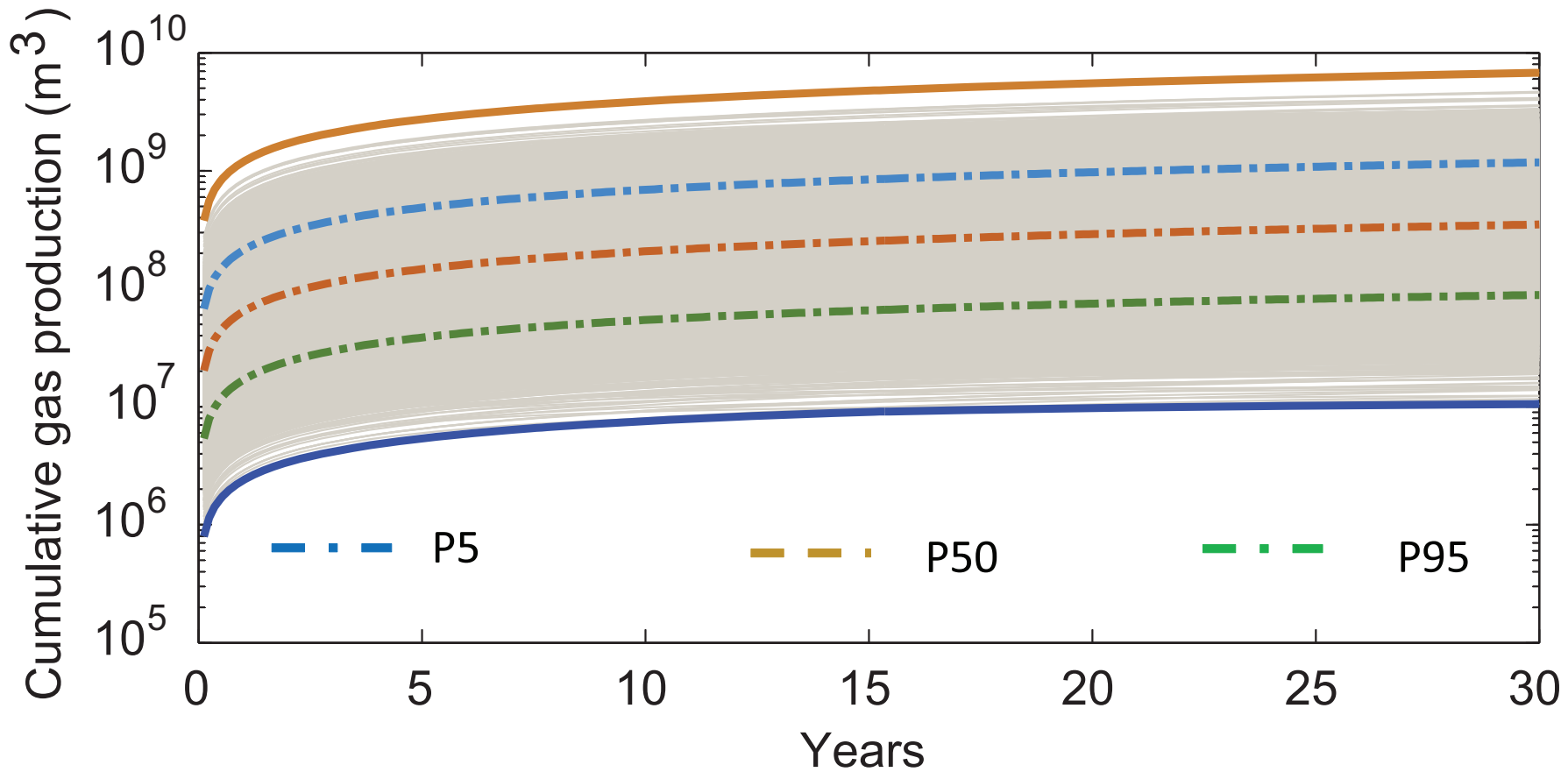


a)

Local relative sensitivity

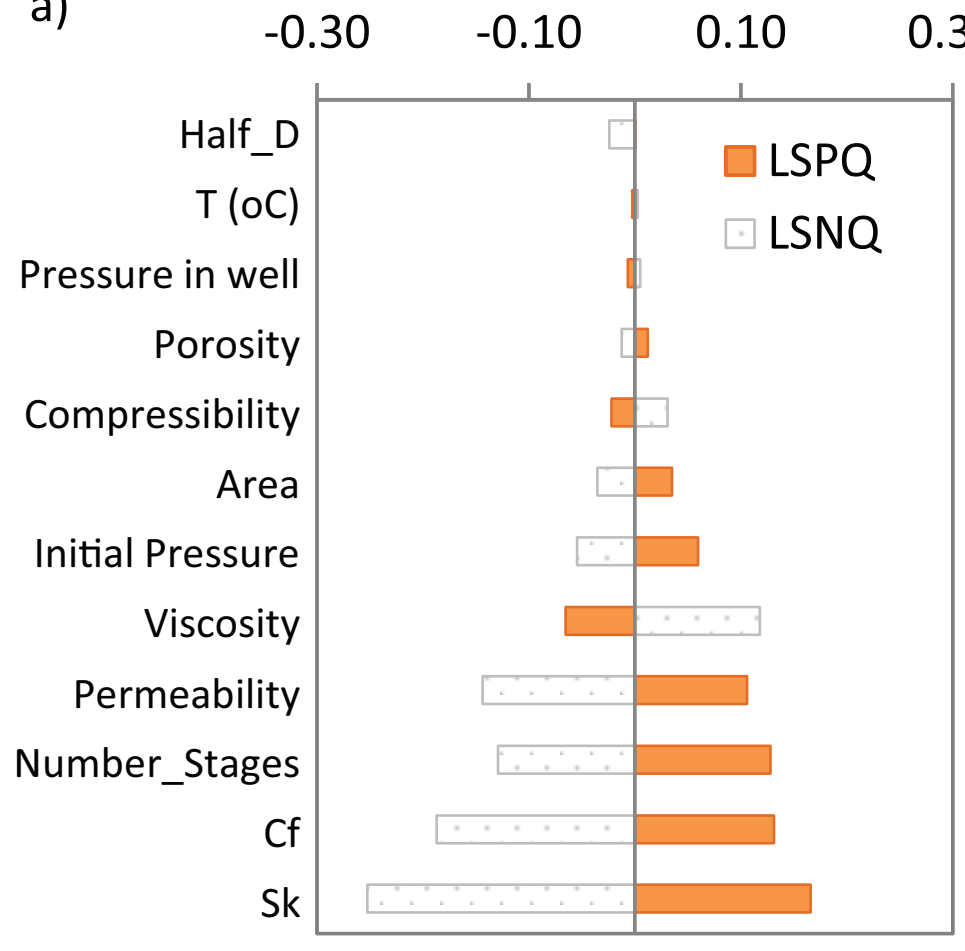

c)

Sobol sensitivity index

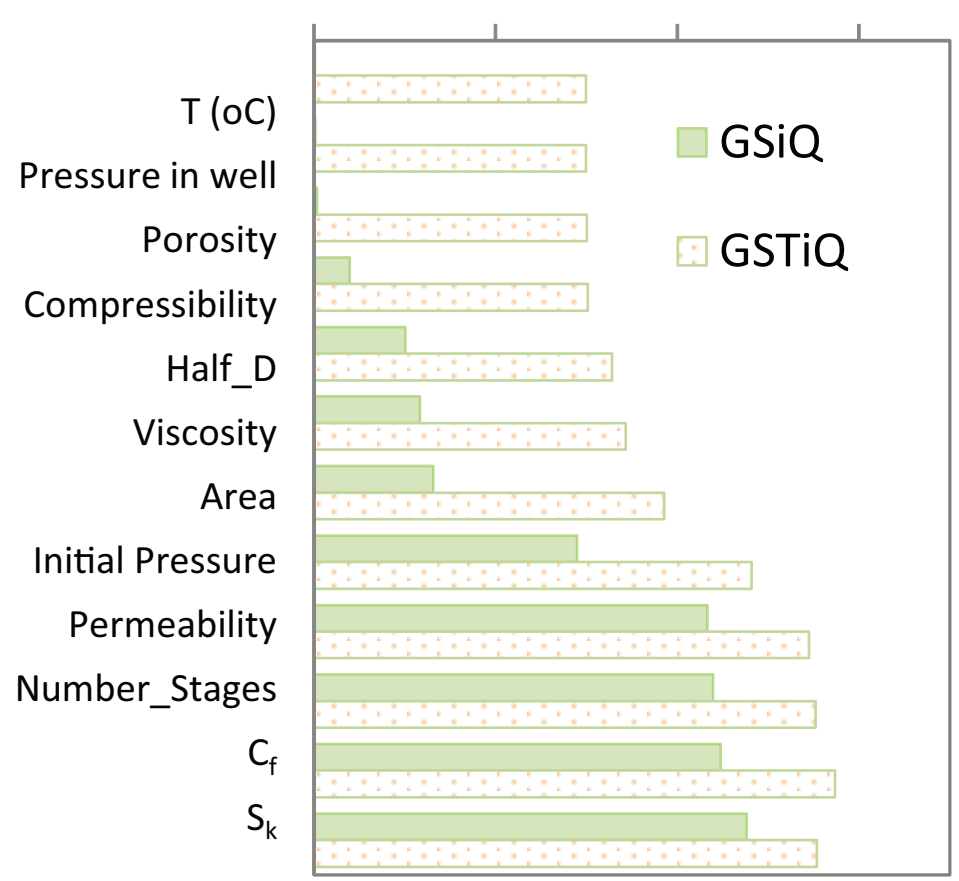

b)

Local relative sensitivity
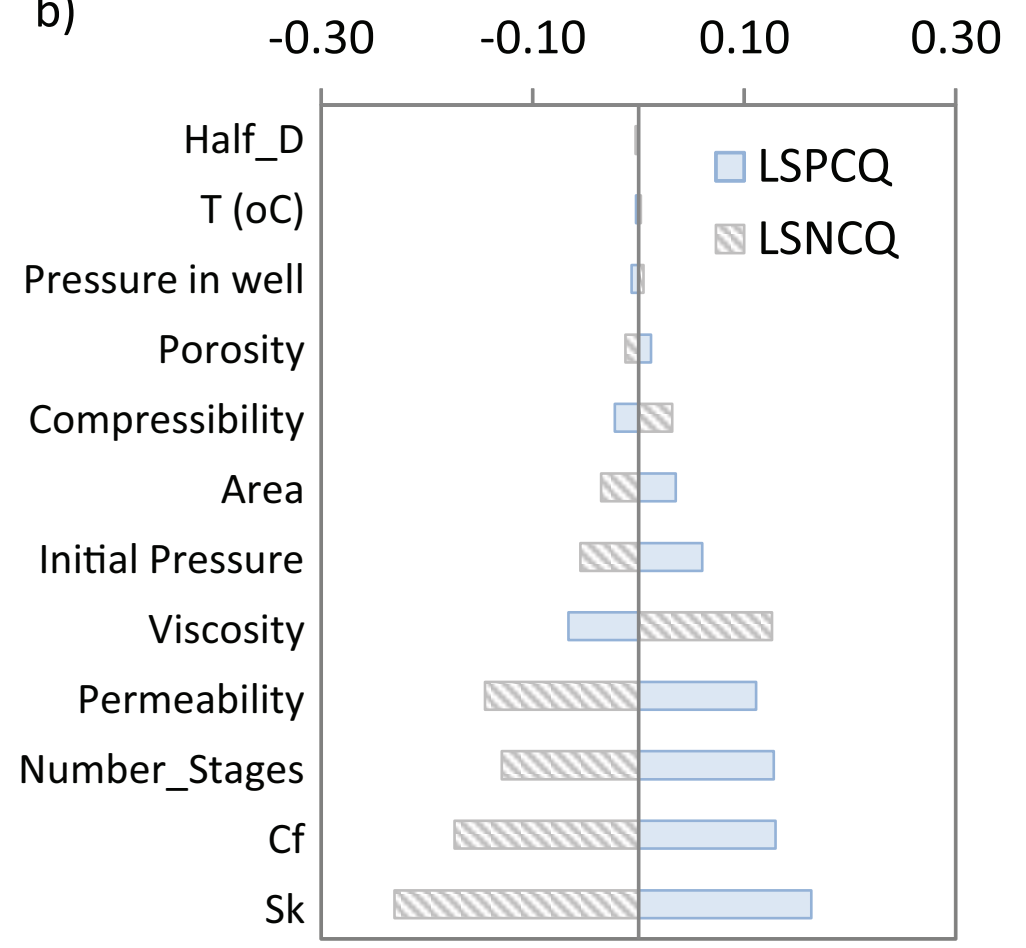

d)

Sobol sensitivity index
0.0
0.1
$0.2 \quad 0.3$

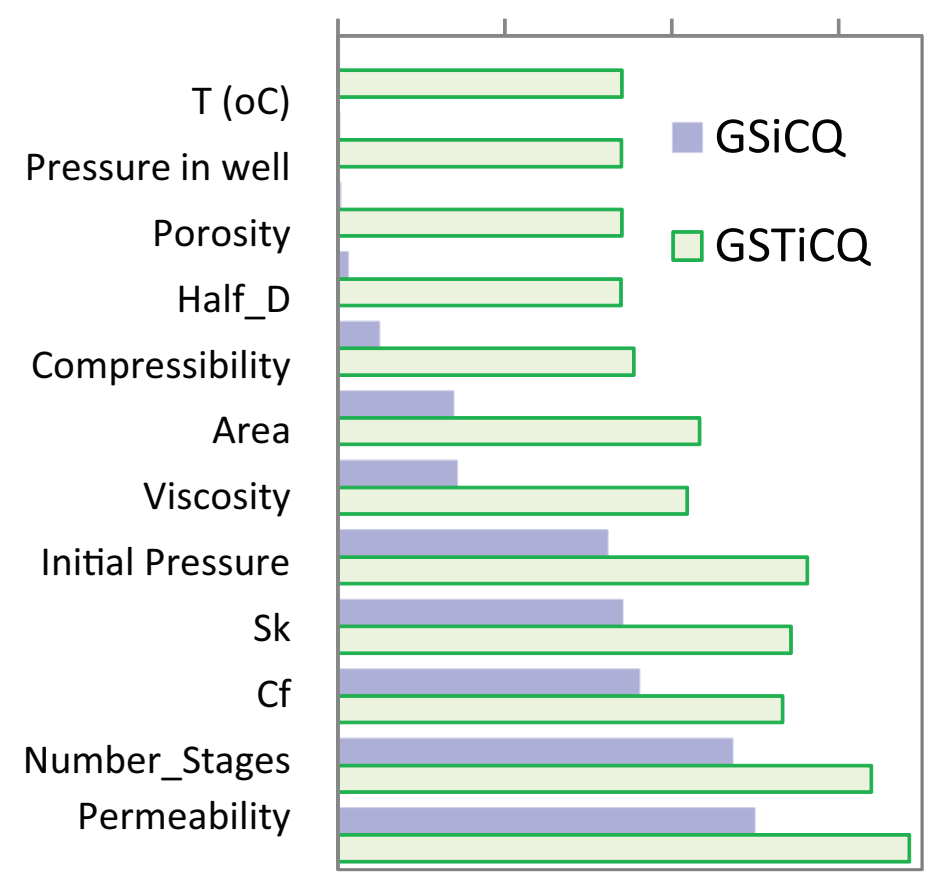


a) $L S P Q$

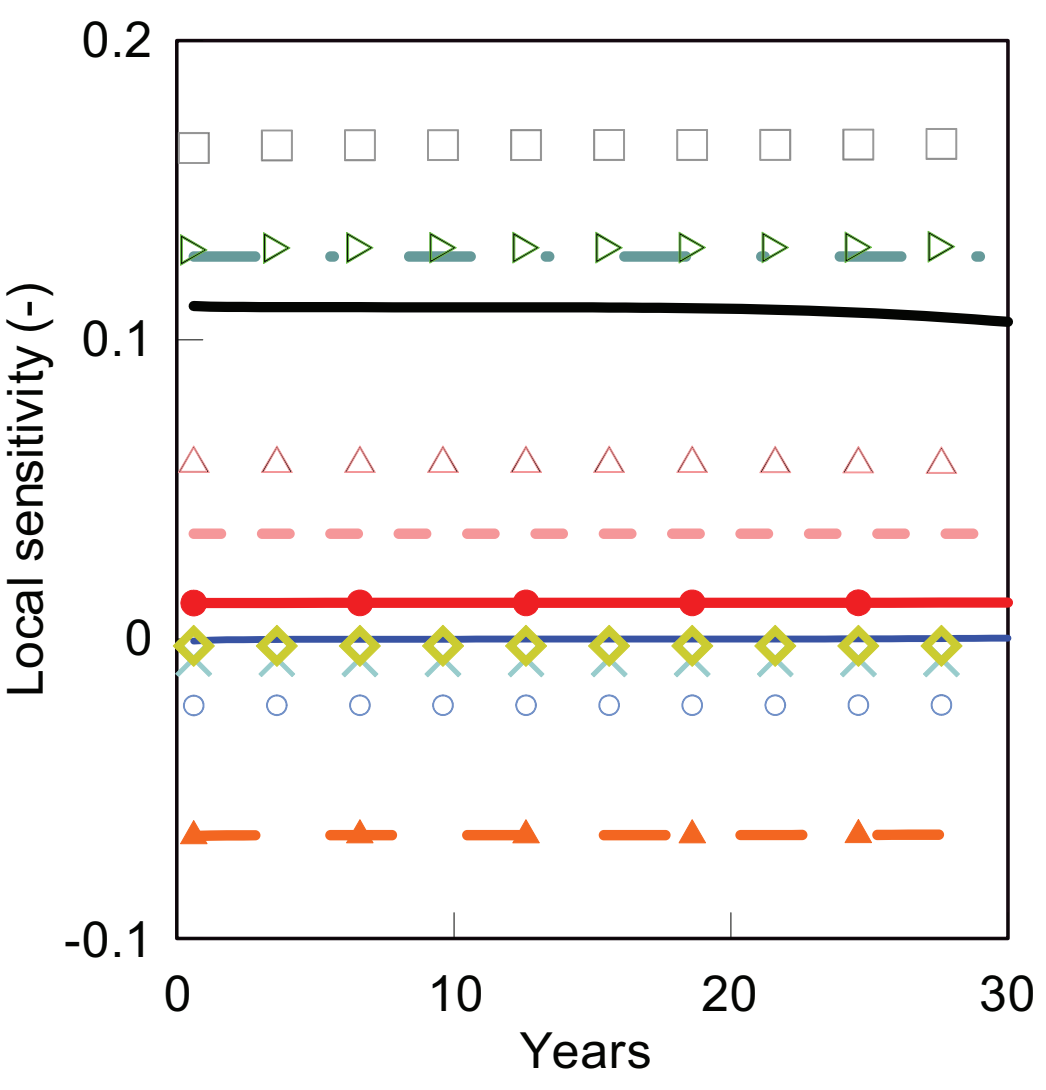

b) LSNQ

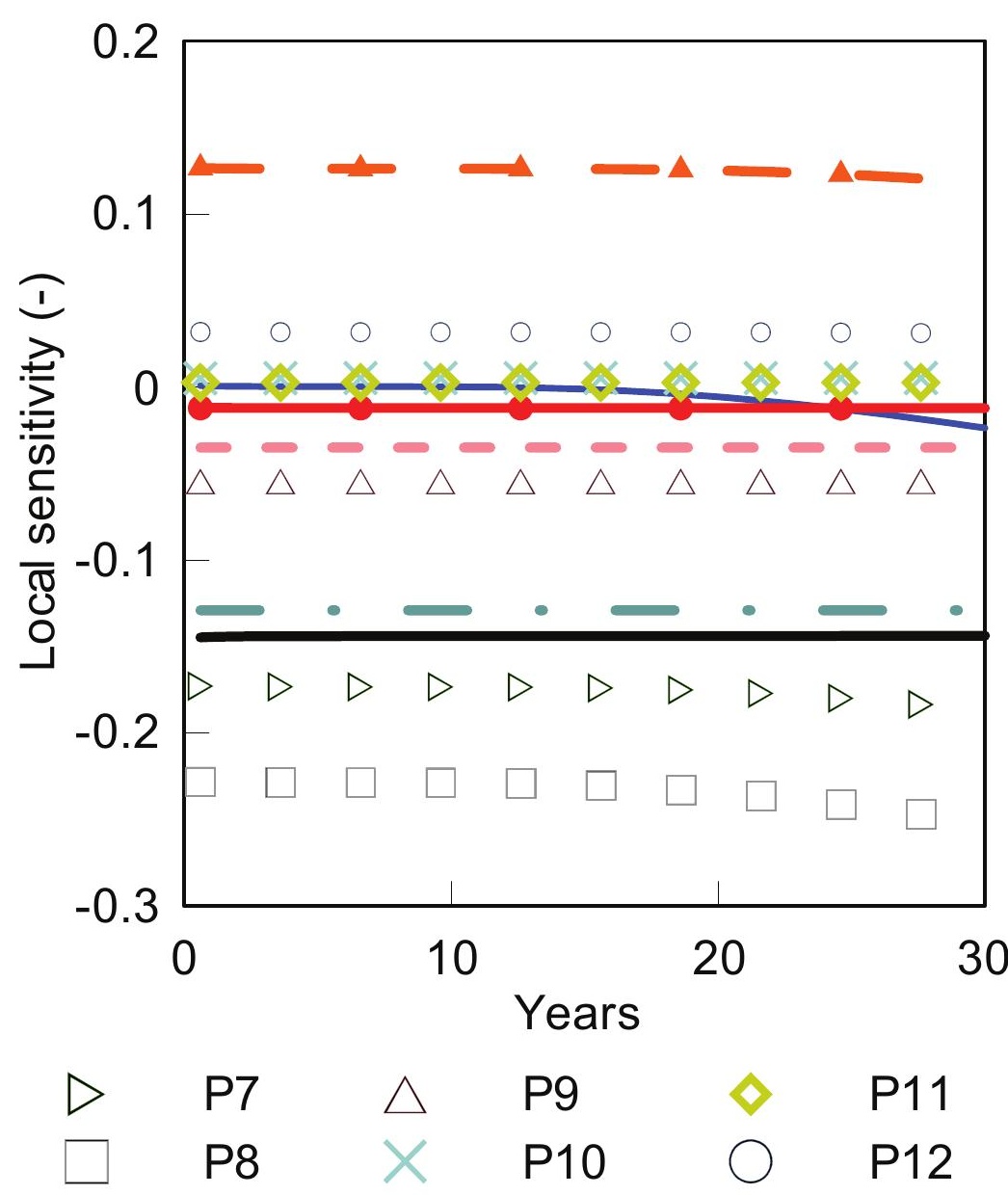



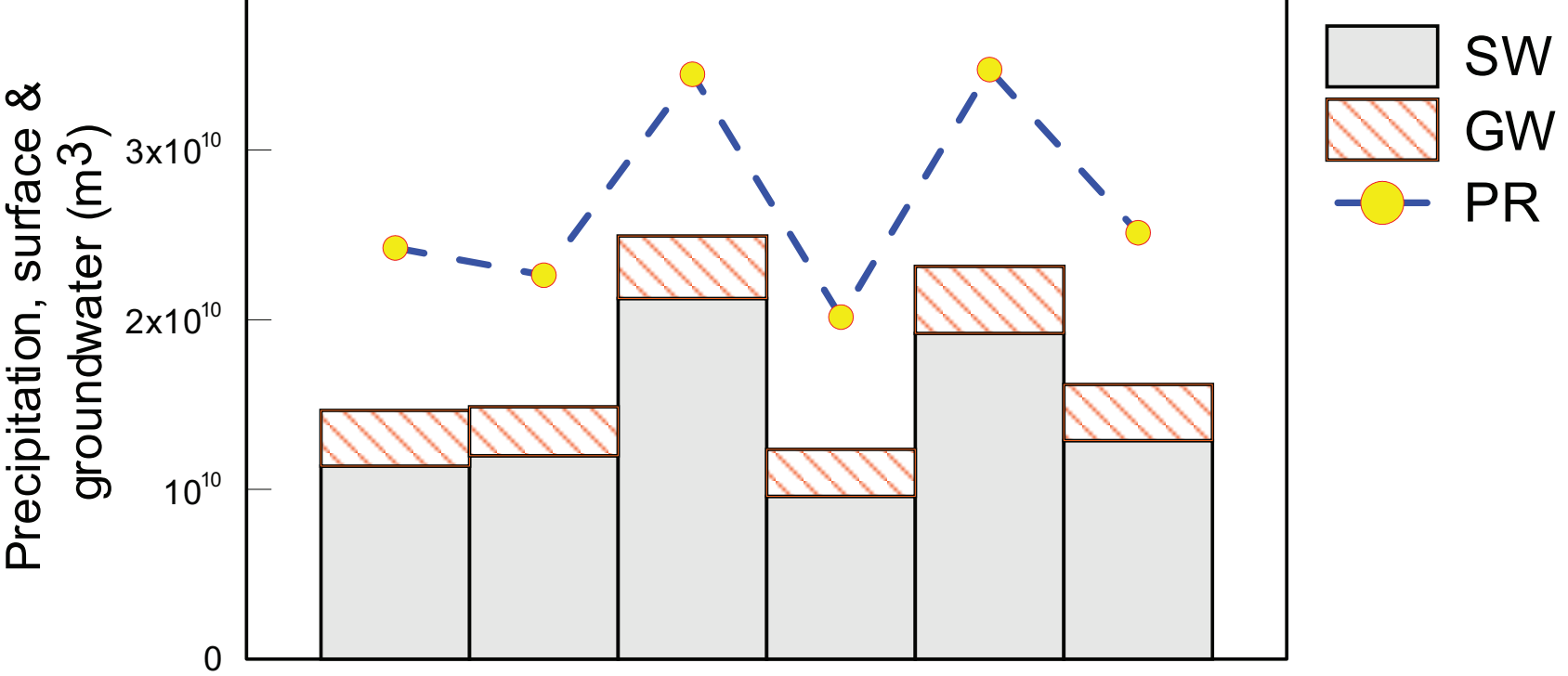

$\begin{array}{llllllll}2007 & 2008 & 2009 & 2010 & 2011 & 2012 & 2013 & 2014\end{array}$

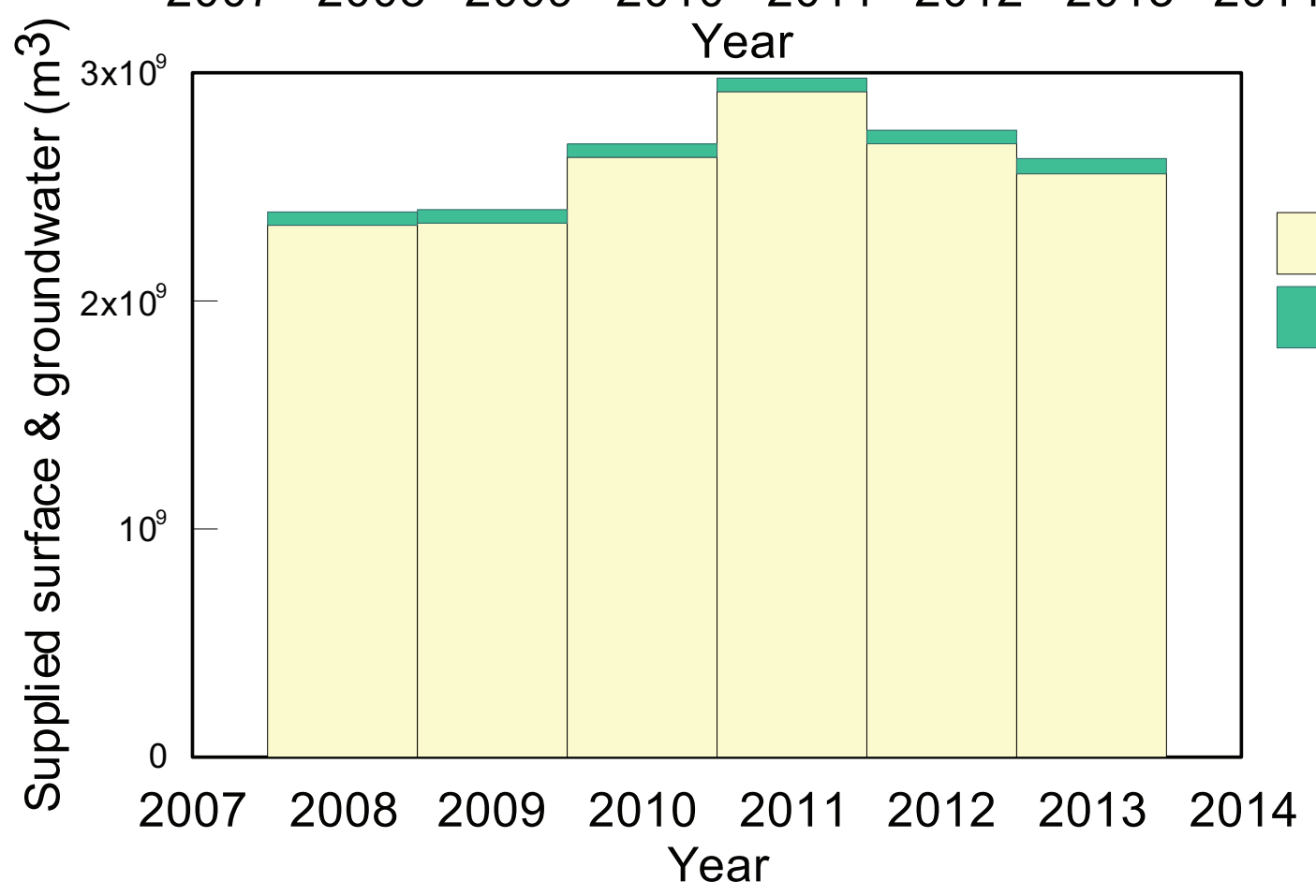

b)

SW Supplied GW Supplied

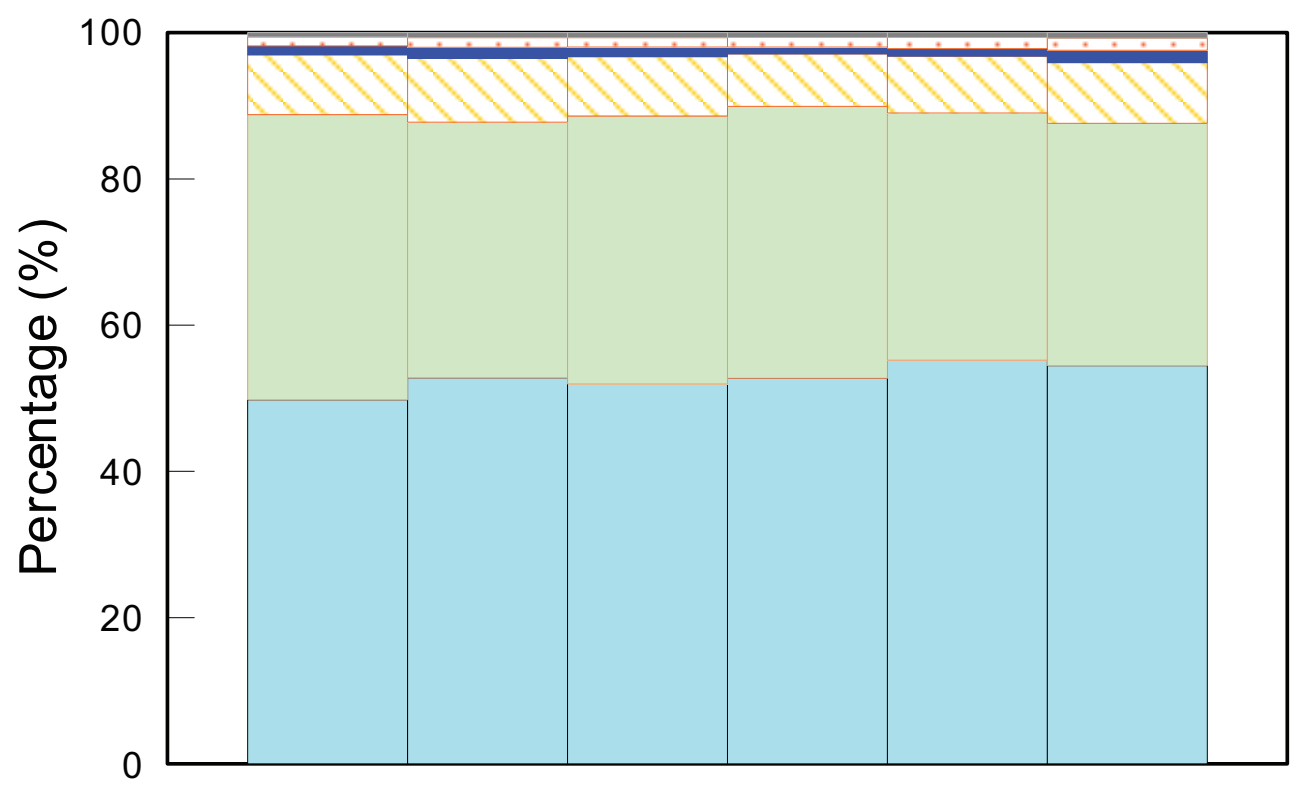

c)

$\begin{array}{llllllll}2007 & 2008 & 2009 & 2010 & 2011 & 2012 & 2013 & 2014\end{array}$

Agricultural Industrial Domestic Stock Municipal Landscape 

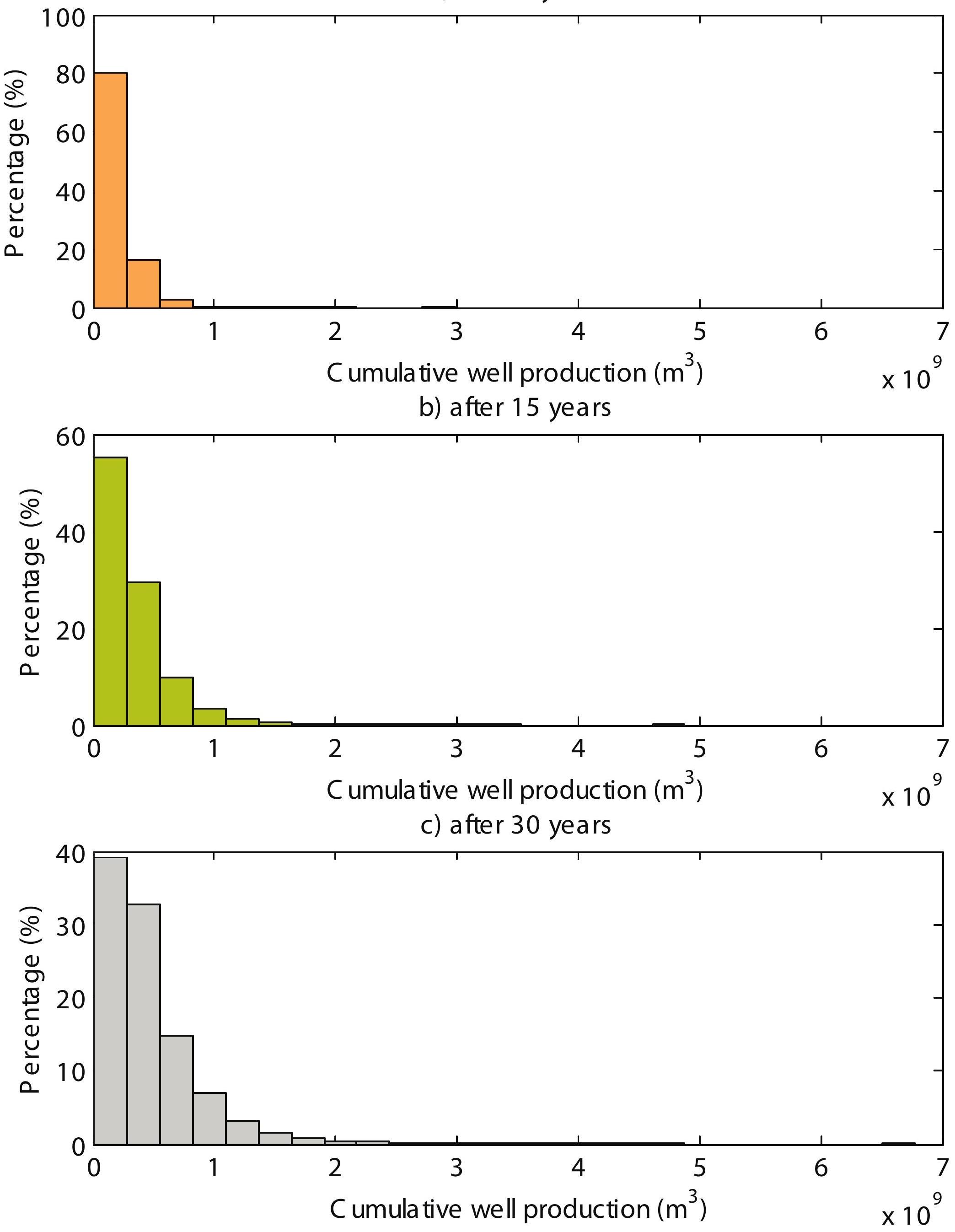


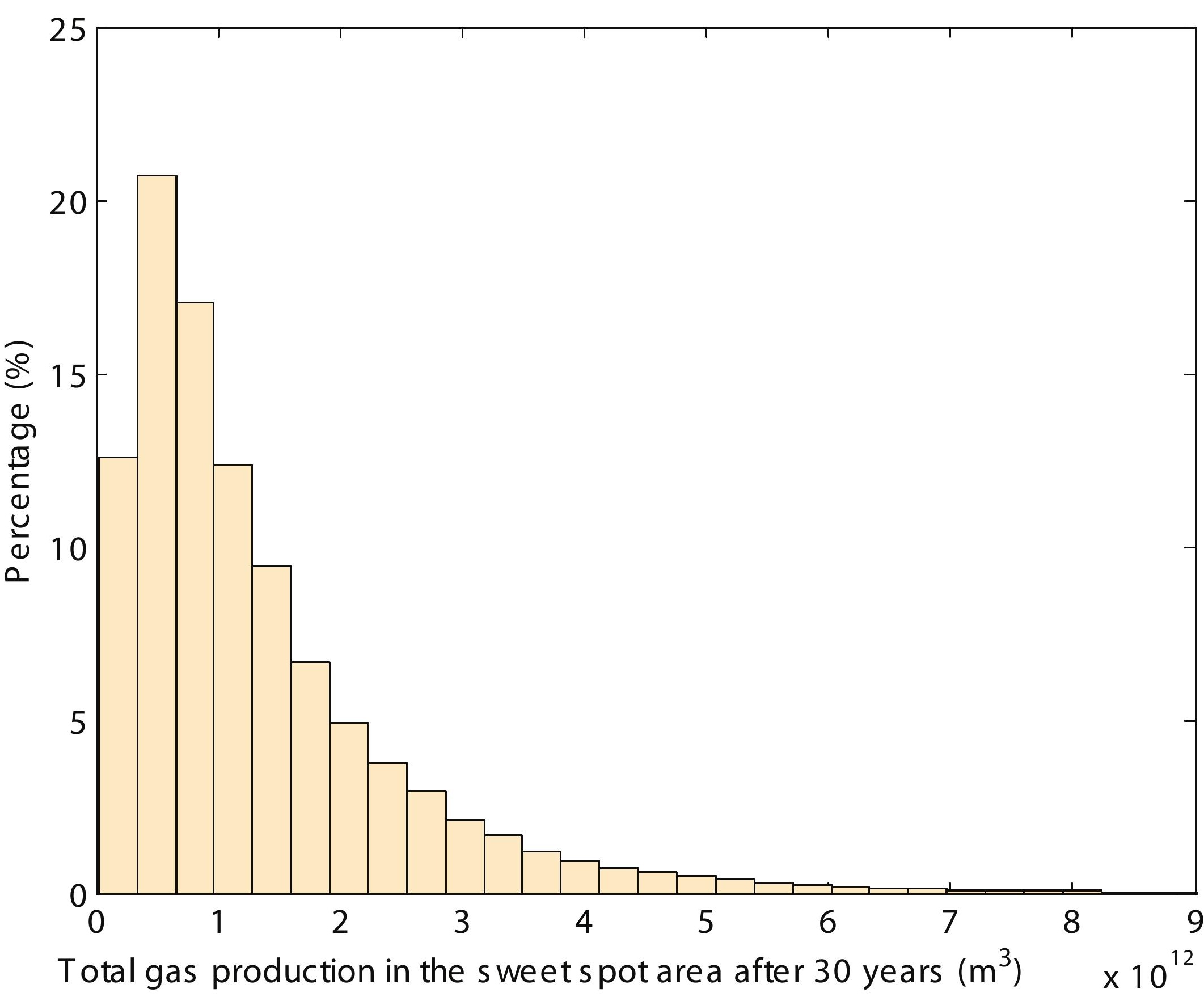

